\begin{tabular}{|l|c|c|c|r|}
\hline $\begin{array}{l}\text { Cuadernos de Investigación Geográfica } \\
\text { Geographical Research Letters }\end{array}$ & 2018 & N $^{\circ} 44(2)$ & pp. 503-534 & $\begin{array}{r}\text { ISSN 0211-6820 } \\
\text { eISSN 1697-9540 }\end{array}$ \\
\hline
\end{tabular}

\title{
CATCHMENT BASED HYDROLOGY UNDER POST FARMLAND ABANDONMENT SCENARIOS
}

\author{
N. LANA-RENAULT ${ }^{1 *}$, M. LÓPEZ-VICENTE ${ }^{2}$, E. NADAL-ROMERO $^{3,4}$, \\ R. OJANGUREN ${ }^{1}$, J.A. LLORENTE ${ }^{1}$, P. ERREA ${ }^{4}$, D. REGÜÉ $S^{4}$, \\ P. RUIZ-FLAÑO ${ }^{1}$, M. KHORCHANI ${ }^{4}$, J. ARNÁEZ ${ }^{1}$, N. PASCUAL ${ }^{1}$ \\ ${ }^{1}$ Área de Geografía Física, Departamento de Ciencias Humanas, Universidad de La Rioja, \\ Edificio Luis Vives, 26004 Logroño, Spain. \\ ${ }^{2}$ Departamento de Suelo y Agua, Estación Experimental de Aula Dei, \\ EEAD-CSIC, Avda. Montañana 1005, 50059 Zaragoza, Spain. \\ ${ }^{3}$ Departamento de Geografía, Instituto Universitario de Ciencias Ambientales (IUCA), \\ Universidad de Zaragoza, Zaragoza, Spain. \\ ${ }^{4}$ Instituto Pirenaico de Ecología, Consejo Superior de Investigaciones Científicas (IPE-CSIC), \\ Campus de Aula Dei, Apto. Correos 13034, 50080 Zaragoza, Spain.
}

\begin{abstract}
Vegetation expansion following farmland abandonment is a complex process that depends on multiple natural and human-induced factors, resulting in differences in the evolution of land cover on former cultivated fields, with various environmental implications. To assess the complexity of the hydrogeomorphological consequences of farmland abandonment, the Instituto Pirenaico de Ecología (CSIC) and the University of La Rioja monitored three small catchments, representative of different post land abandonment scenarios, in the Pyrenees and Iberian Range respectively. In the Pyrenees, a fourth small catchment, covered by natural forest, was monitored as a reference for an undisturbed environment. This study describes the evolution of land use in the abandoned catchments and examines its implications on catchment hydrological connectivity. It also analyses the hydrological responses of the three abandoned scenarios to similar rainfall events, and compares them to that of natural forested areas. Vegetation tended to increase in the three catchments, but there were important differences in the characteristics of the current land cover. Arnás, the catchment left to a process of natural revegetation, contained a mosaic of shrubs $(64 \%)$ and forest $(27 \%)$ at different stages of succession, largely conditioned by the topography and soil properties. Araguás_afforestation was extensively afforested in the 1960s, with 75\% of this catchment currently covered by forest, most of it planted artificially. In Munilla, occupied by terraced fields, vegetation recovery was partly restrained by the introduction of cattle, and $80 \%$ of the catchment was covered by sparse shrubs. Land abandonment resulted in a general reduction in computed hydrological connectivity in the three studied catchments, except in localized areas close to the main channel, new forest roads and trails, and upstream of terrace wall collapses, all areas of increased hydrological
\end{abstract}


connectivity. The decrease in hydrological connectivity was much lower in Munilla, characterized by an absence of dense vegetation and still dominated by a terraced topography. The hydrological responses of the catchments to similar rainfall events differed significantly, showing the influence of not only vegetation cover but of the properties of soil remaining after previous agricultural activities. Significant storm-flow discharge was observed in Arnás, even under dry conditions, with high peakflows and fast responses. Lower streamflow response was observed in Araguás_Afforestation under dry conditions; however, once the soils were wet the hydrological response was notable and was characterized by high peakflow. The response under afforested trees differed greatly from that of a catchment covered by natural forest, with the latter characterized by gentler hydrographs. The hydrological response in Munilla was the lowest, with long response times and recessions, associated with the thick soils of the terraced fields. These results demonstrated the large variability of post land abandonment scenarios and associated hydrological implications, and highlighted the need to consider these differences to reduce future uncertainties in forecasting water resources and soil conservation.

\section{Hidrología a escala de cuenca en escenarios posteriores al abandono de tierras}

RESUMEN. El aumento de la vegetación tras el abandono de tierras es un proceso complejo que depende tanto de factores naturales como antropogénicos. Esto implica que la evolución de la cubierta vegetal no es siempre igual, lo cual conlleva consecuencias ambientales diversas. Con el fin de evaluar la complejidad de las consecuencias hidrogeomorfológicas del abandono de tierras, el Instituto Pirenaico de Ecología (CSIC) y la Universidad de La Rioja monitorizaron tres pequeñas cuencas representativas de diferentes escenarios post abandono en el Pirineo y en el Sistema Ibérico. Asimismo, se monitorizó una pequeña cuenca cubierta por bosque en el Pirineo, representativa de un ambiente que no ha sido alterado. En este estudio se describe la evolución de los usos del suelo en las cuencas abandonadas y se examinan sus implicaciones en la conectividad hidrológica. También se analizan las respuestas del caudal de los tres ambientes abandonados ante eventos pluviométricos similares y se comparan con las de un ambiente forestal. La vegetación aumentó en las tres cuencas pero se observaron diferencias importantes en las características actuales de la cubierta del suelo. Arnás, la cuenca sometida a un proceso de revegetación natural, constituye un mosaico de matorrales (64\%) y bosques (27\%) que se encuentran en diferentes estadios en la sucesión vegetal en función de la topografía y las características de los suelos. Araguás_Repoblación fue reforestada en los años 1960 y el 75\% de su superficie está actualmente cubierto por bosque, la mayoría de repoblación. En Munilla, ocupada por terrazas de cultivo, el crecimiento de la vegetación se ha visto limitado por la introducción de ganado en régimen extensivo y el $80 \%$ de su superficie se encuentra ocupado por matorral disperso. El abandono de tierras conllevó una disminución generalizada de la conectividad hidrológica a escala de cuenca, excepto en zonas muy localizadas próximas a los cauces y a nuevas pistas forestales así como aguas arriba de los 
derrumbamientos en los bancales abandonados, que presentaron un incremento en los valores de conectividad. No obstante, este descenso en la conectividad hidrológica fue mucho menor en Munilla, caracterizada por una ausencia de vegetación densa y dominada todavía por una topografía aterrazada. La respuesta del caudal generada por eventos pluviométricos similares fue muy diferente en cada una de estas cuencas, evidenciando la importancia que tiene tanto la vegetación como unos suelos que todavía poseen características heredadas de un pasado agrícola. La respuesta hidrológica en Arnás fue intensa, incluso en condiciones secas, con picos de caudal elevados y tiempos de respuesta cortos. En condiciones secas, la respuesta del caudal en Araguás_repoblación fue de menor magnitud; no obstante, en condiciones húmedas, la cuenca registró una respuesta notable y caracterizada por un pico de caudal elevado. La respuesta hidrológica del ambiente repoblado fue muy diferente a la de un bosque natural, con hidrogramas de crecida mucho más suaves. Munilla registró la respuesta de caudal más limitada y ésta estuvo caracterizada por tiempos de respuesta lentos y curvas de recesión largas, asociados a la presencia de terrazas de cultivo con suelos profundos. Estos resultados ponen en evidencia la gran variabilidad de escenarios fruto del abandono de tierras y resalta la necesidad de considerar estas diferencias a la hora de reducir la incertidumbre en las predicciones futuras sobre la disponibilidad de los recursos hídricos y la conservación del suelo.

Key words: farmland abandonment, hydrological connectivity, storm-flow, headwater catchment, Mediterranean mountain, Pyrenees, Iberian Range.

Palabras clave: abandono de tierras, conectividad hidrológica, escorrentía de crecida, cuenca de cabecera, montaña mediterránea, Pirineos, Sistema Ibérico.

Received: 8 November 2017 Accepted: 13 December 2017

*Corresponding author: Noemí Lana-Renault, Área de Geografía Física, Departamento de Ciencias Humanas, Universidad de La Rioja, Edificio Luis Vives, 26004 Logroño, Spain. E-mail address: noemi-solange.lana-renault@unirioja.es

\section{Introduction}

Among the major changes in many rural areas in Europe throughout the 19th and 20th centuries is the abandonment of farmland (García-Ruiz and Lana-Renault, 2011; Lasanta et al., 2017a), resulting in the progressive revegetation of formerly cultivated hillslopes and grazing areas. The complex succession of plants on arable land has had significant environmental consequences. Ecologically, natural recovery due to farmland abandonment results in landscape homogeneity, which has implications for biodiversity and increases forest fire risk (MacDonald et al., 2000). Hydrologically, the growth of vegetation directly affects interception, infiltration, evapotranspiration and soil storage of water, usually reducing runoff production and peak flows (López-Moreno et al., 2008; Lana-Renault et al., 2011). Vegetation expansion also causes a shrinkage of sediment sources (Bakker et al., 
2008; Lana-Renault and Regüés, 2009) and a decrease in sediment supply from hillslopes to channels (Piégay et al., 2004; Quiñonero-Rubio et al., 2016), reducing the sedimentation levels of reservoirs, rivers and coastal areas (Keesstra, 2007; López-Moreno et al., 2011) and altering stream morphology, including the narrowing and incision of alluvial plains (Beguería et al., 2006; Sanjuán et al., 2016). The mechanisms by which changes in a landscape (e.g. due to farmland abandonment) affect the transfer of water and sediment through a drainage basin are a "hot topic" of hydrological and geomorphological research and have led to the increased use of the concept of hydrological connectivity. Recent studies (López-Vicente et al., 2013a, 2017a; Quiñonero-Rubio et al., 2013; Buendía et al., 2016) have shown that farmland abandonment usually decreases hydrological connectivity, mostly because of an increase in vegetation cover.

Many mountainous areas of the Mediterranean region have undergone natural revegetation of former agricultural land along with extensive afforestation programs by national forest services to improve the use of abandoned land as a resource and to control hydrological and soil erosion processes (Ortigosa et al., 1990; Vallauri et al., 2002). Because few studies to date have assessed the implications of these programs on hydrological response (Richard and Mathys, 1999; Chirino et al., 2001; Piégay et al., 2004), it remains unclear whether the hydrology of an afforested area is comparable to that of a natural forest, with differences in soil and forest canopy properties. Although a recent study showed that, compared with a natural forest, an afforested area recorded greater storm-flows and peak discharges, faster response times and shorter recession limbs (Nadal-Romero et al., 2016), more process-oriented research is needed to better understand these differences.

Abandoned farmland in the Mediterranean region includes sloping fields and terraced areas (Lasanta et al., 2017b). The effects of farmland abandonment on terraced landscapes are manifold, because these areas have been conditioned by disturbances in topography and soil characteristics (Seeger and Ries, 2008) established during terrace construction. In addition to the recovery of vegetation, the lack of maintenance resulting from farmland abandonment may cause failures in the terrace risers, often followed by small mass movements and gullying (Lesschen et al., 2008; Solé-Benet et al., 2010; Arnáez et al., 2015, 2017), resulting in new sediment sources on the hillslopes. The off-site effects of these phenomena, which depend on the spatial distribution of sediment sources, water transfer paths and local sinks, are still unclear, due in part to the lack of studies that have investigated the hydrology of abandoned terraced landscapes, especially at the catchment scale. The abandonment of agricultural terraces has been shown to enhance saturation of the inner parts of the terraces, increasing overland storm flow (Gallart et al., 1994). However, these findings may not be applicable to other terraced areas, as terraced areas have very complex hydrological behavior, characterized predominantly by saturation-excess runoff (Latron and Gallart, 2008; Nunes et al., 2016) or deep subsurface and pipe flow (Preti et al., 2017), depending on the properties of each site.

Most abandoned areas in the Mediterranean region are located in the uplands, which are the main sources of water for the lowlands, the areas of greatest water demand (García-Ruiz et al., 2011). The expected increase in vegetation in these abandoned areas during the next few decades (Verburg and Overmars, 2009; Lasanta et al., 2017a) will likely have important environmental implications, making water availability in this region challenging. The heterogeneity of landscapes present in mountainous regions of 
the Mediterranean increases the uncertainty in forecasting changes in water resources and soil conservation. Thus, there is an urgent need to assess the hydrological implications of different farmland abandonment scenarios, including the recovery of natural vegetation in sloping fields and terraced areas, as well as afforestation practices.

This study presents several key hydrological results obtained from research undertaken in three small headwater catchments, representing farmland abandonment scenarios, and one small catchment, representing an undisturbed forested environment. In the 1990s, the Instituto Pirenaico de Ecología (Spanish Research Council, CSIC) monitored two adjacent small headwater catchments, differing in their history of land use, in the mid-altitude mountains of the Central Spanish Pyrenees to assess the effect of land use changes on water resources and soil erosion. The Arnás catchment $\left(2.84 \mathrm{~km}^{2}\right)$ was heavily cultivated with cereal crops in nonterraced fields until the $1950 \mathrm{~s}$, after which it was abandoned and left to natural revegetation. The San Salvador catchment $\left(0.92 \mathrm{~km}^{2}\right)$, which was covered by dense natural forest, was representative of an undisturbed environment. In 2007, the Araguás_Afforestation catchment $\left(0.12 \mathrm{~km}^{2}\right)$ was incorporated into this study; this catchment, located in the Spanish Pyrenees and close to the Arnás and San Salvador catchments was formerly cultivated, but afforested in the late 1960s. In 2012, the Munilla catchment $\left(1.92 \mathrm{~km}^{2}\right)$, located in the Iberian Range and consisting mostly of abandoned terraced fields, was incorporated into this study and monitored by the University of La Rioja. Working at the small $\left(<10 \mathrm{~km}^{2}\right)$ catchment scale has several advantages. First, catchments are closed systems that enable the elaboration of water and sediment balances and the study of interactions between slopes and channels. In addition, the small sizes of these catchments allow the assessment of environments that are homogeneous in lithology, topography and land cover. Their small size also allows processes to be observed and high-density variables to be measured (Holko et al., 2015). All this information can be used to calibrate and validate models, especially physical-based approaches that require greater parameterization.

The objectives of this study are i) to report the changes in land use from 1956 to the present in three catchments representing different post farmland abandonment scenarios; ii) to assess changes in hydrological connectivity during the process of farmland abandonment; and iii) to analyze their hydrological responses to similar rainstorm events and compare them to that of natural forested areas.

\section{The catchments}

The Arnás, San Salvador and Araguás_Afforestation catchments are located in the upper Aragón River valley, in the Central Spanish Pyrenees, between 875 and 1340 ma.s.l. (Fig. 1). The bedrock is Eocene flysch, composed of thin, alternating layers of sandstones and marls. The three catchments are close to each other and share similar climatic conditions. Mean annual rainfall is $926 \pm 182 \mathrm{~mm}$ in Arnás, $935 \pm 171 \mathrm{~mm}$ in San Salvador, and $759 \pm 202 \mathrm{~mm}$ in Araguás_Afforestation. Most of the rainfall in these catchments occurs during the autumn and spring and is associated with cyclonic fronts, whereas intense short-duration convective storms are relatively frequent in summer. Mean annual temperature is $10^{\circ} \mathrm{C}$, with snow falling only occasionally. Table 1 summarizes the main characteristics of these catchments. 


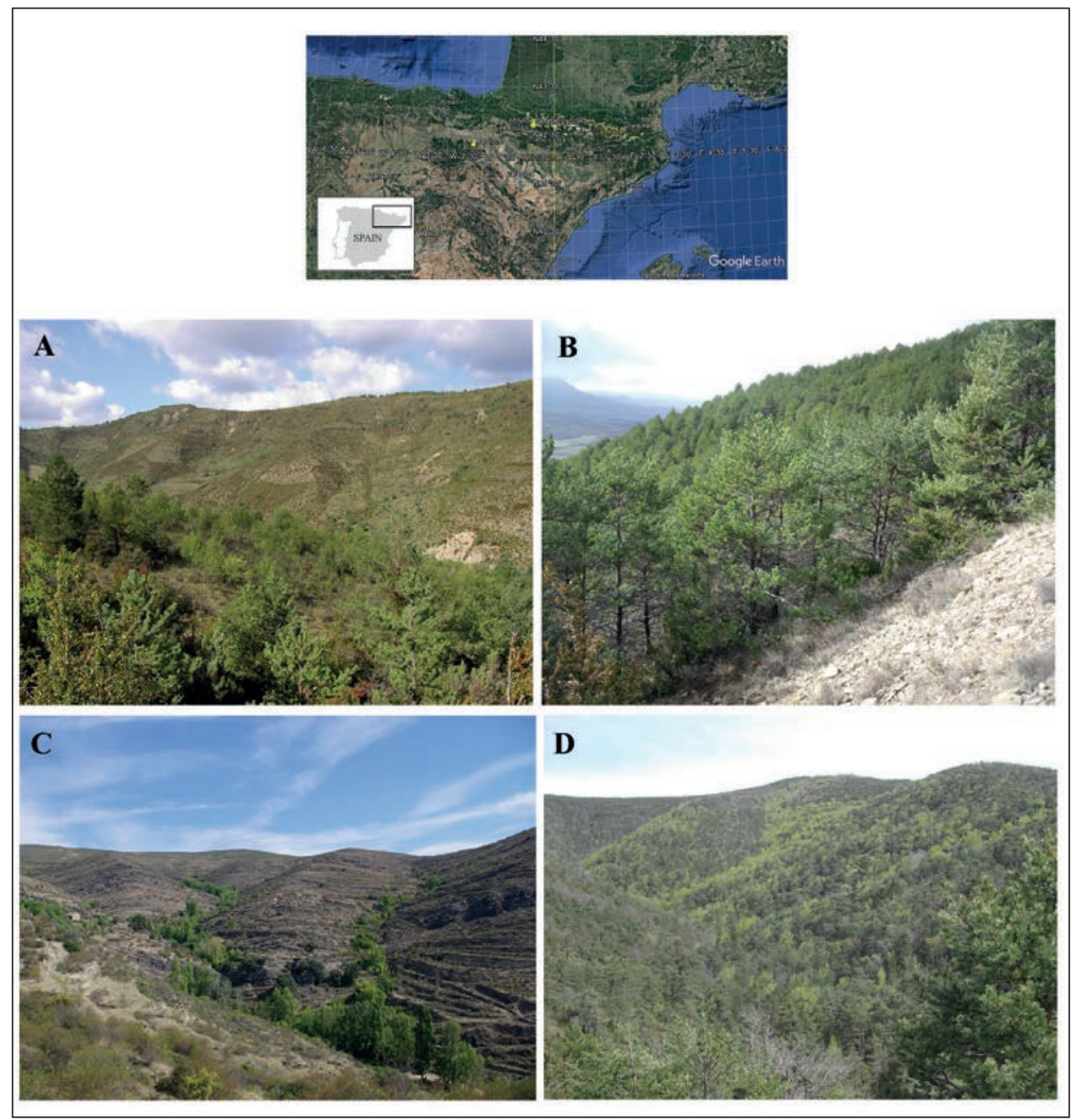

Figure 1. Location of the study catchments in northern Spain and overviews of A) the catchment recolonized by native vegetation (Arnás); B) the afforested catchment (Araguás_afforestation); C) the catchment with agricultural terraces (Munilla); and D) the catchment with natural forest cover (San Salvador).

The Arnás catchment $\left(2.84 \mathrm{~km}^{2}\right)$ has a west-east orientation, resulting in an asymmetry between north- and south-facing slopes (cuesta relief). The gentler northeastfacing slope is marked by an undulating topography with old scars and stable deep mass movement deposits. Most soils are brown and contain deep haplic kastanozems, with a high content of organic matter (Navas et al., 2005). The southwest-facing slope is steeper, with its upper parts showing recent debris flows, disconnected from the drainage network. Soils are dominated by compact and shallow calcaric regosols, resulting from prior human activities (Navas et al., 2008). In general, soils have a 
silt texture, although the percentage of clay can be high at some locations (Seeger and Ries, 2008). Because the Arnás catchment was abandoned, it has been recolonized by shrubs (e.g., Genista scorpius, Echinospartum horridum, Juniperus communis, Rosa gr. canina and Buxus sempervirens), which provide a lower density cover on southwestern-facing slopes, and by patches of developing forest (Pinus sylvestris and Quercus faginea) that mainly occupy the northeast-facing slope.

The San Salvador catchment $\left(0.92 \mathrm{~km}^{2}\right)$ has an east-west orientation and is characterized by a deep, stony colluvium covering most of the slopes, thus accounting for the lack of geomorphological contrasts. Soils are mainly composed of well-developed kastanozems and cambisols with a silt texture. This catchment is almost completely covered by a dense natural forest of Scots pine (P. sylvestris), in combination with beech trees (Fagus sylvatica) in the shady concavities and oaks $(Q$. faginea) in areas with a sunny aspect.

Table 1. General characteristics of the study catchments.

\begin{tabular}{|c|c|c|c|c|}
\hline & Arnás & San Salvador & Araguás_Afforestation & Munilla \\
\hline Area $\left(\mathrm{km}^{2}\right)$ & 2.84 & 0.92 & 0.12 & 1.92 \\
\hline $\begin{array}{l}\text { Min-Max } \\
\text { altitudes } \\
\text { (m a.s.l.) }\end{array}$ & $910-1340$ & $875-1300$ & $920-1105$ & $775-1175$ \\
\hline Bedrock & flysch & flysch & flysch & Weald facies \\
\hline $\begin{array}{l}\text { Mean slope } \\
\left(\mathrm{m} \mathrm{m}^{-1}\right)\end{array}$ & 0.38 & 0.52 & 0.38 & 0.40 \\
\hline Soil types & $\begin{array}{r}\text { Haplic } \\
\text { Kastanozems and } \\
\text { Calcaric Regosols } \\
\end{array}$ & $\begin{array}{r}\text { Kastanozems } \\
\text { and Cambisols }\end{array}$ & Calcaric regosols & Cambisols \\
\hline Soil texture & Silt & Silt & Silt-loam & Silt-loam \\
\hline Land cover & $\begin{array}{r}\text { Natural } \\
\text { recolonization } \\
\text { with shrubs }(G . \\
\text { scorpius, } B . \\
\text { sempervirens }) \\
\text { and forest }(P . \\
\text { sylvestris }) \\
\end{array}$ & $\begin{array}{r}\text { Natural forest } \\
\text { (P. sylvestris) }\end{array}$ & $\begin{array}{r}\text { Afforestation }(P . \\
\text { sylvestris, } P . \text { nigra })\end{array}$ & \begin{tabular}{|} 
Abandoned \\
terraces \\
recolonized with \\
sparse shrubs \\
(G. scorpius, $C$. \\
laurifolius $)$
\end{tabular} \\
\hline $\begin{array}{l}\text { Annual rainfall } \\
(\mathrm{mm})\end{array}$ & $926 \pm 182$ & $935 \pm 171$ & $759 \pm 202$ & $500-600$ \\
\hline $\begin{array}{l}\text { Measurement } \\
\text { equipment for } \\
\text { hydrological } \\
\text { variables and } \\
\text { frequency of } \\
\text { data collection }\end{array}$ & \begin{tabular}{|l|} 
- 3 tipping \\
buckets \\
-1 weather station \\
$(15$ min) \\
-1 gauging \\
station at the \\
outlet $(5$ min $)$ \\
-4 to 7 \\
piezometers (20 \\
min)
\end{tabular} & $\begin{array}{l}\text { - } 3 \text { tipping } \\
\text { buckets } \\
-1 \text { weather } \\
\text { station }(15 \mathrm{~min}) \\
-1 \text { gauging } \\
\text { station at the } \\
\text { outlet }(5 \text { min }) \\
-2 \text { piezometers } \\
(20 \text { min) }\end{array}$ & $\begin{array}{l}-2 \text { tipping buckets } \\
-1 \text { gauging station at } \\
\text { the outlet ( } 5 \mathrm{~min}) \\
-5 \text { piezometers ( } 20 \\
\text { min) }\end{array}$ & $\begin{array}{l}-2 \text { tipping } \\
\text { buckets } \\
-1 \text { weather } \\
\text { station }(10 \mathrm{~min}) \\
-1 \text { gauging } \\
\text { station at the } \\
\text { outlet }(10 \mathrm{~min}) \\
-4 \text { piezometers } \\
(10 \text { min })\end{array}$ \\
\hline
\end{tabular}


The Araguás catchment $\left(0.45 \mathrm{~km}^{2}\right)$ is north-south oriented, consisting of a southern sector largely occupied by badlands and a northern sector that corresponds to the headwaters of the catchment and is afforested. This sub-catchment $\left(0.12 \mathrm{~km}^{2}\right)$, called the Araguás_Afforestation catchment, was previously cultivated with cereal crops in terraced fields and was afforested in the late 1960s with black pine (P. nigra) and Scots pine ( $P$. sylvestris), both of which are about $6 \mathrm{~m}$ in height. The soils are stony and shallow calcaric regosols, resulting from centuries of cultivation, and they are characterized by a silty-loam texture.

The Munilla catchment $\left(1.92 \mathrm{~km}^{2}\right)$ is located in the Camero Viejo, in the Iberian Range, between 775 and $1175 \mathrm{~m}$ a.s.l. The bedrock in this catchment is composed of a series of mesozoic materials (Weald facies), including marls and siltstones, alternating with thick layers of calcareous sandstones. Annual rainfall ranges between 500 and 600 $\mathrm{mm}$, with most rain occurring in spring and summer (Cuadrat and Vicente-Serrano, 2008). Rain also occurs during the summer, usually as convective storms, and there is occasional snowfall in winter. Mean annual temperature is $11^{\circ} \mathrm{C}$. Previously, most of the hillslopes were cultivated with cereal crops in terraced fields that occupy $40 \%$ of the catchment. After abandonment, they have been recolonized by sparse shrubs (G. scorpius and Cistus laurifolius). The introduction of extensive cattle grazing has restrained the development of forests. Terraces vary in size and are delimited by stone walls between 1 and $4 \mathrm{~m}$ in height. Soils are classified as Cambisols with a silty-loam texture (Oserín, 2006).

Long-term monitoring of these catchments has provided useful hydrogeomorphological information, enabling study of the factors that explain their hydrological and sedimentological responses (Lorente et al., 2000; Seeger et al., 2004; García-Ruiz et al., 2005; Lana-Renault and Regüés, 2007; Lana-Renault et al., 2007; Serrano-Muela et al., 2008; Llorente-Adán et al., 2015; Nadal-Romero et al., 2016), their water and sediment sources (González et al. 1997; Lana-Renault and Regüés 2009; Butzen et al., 2011; Lana-Renault et al., 2014a), the dynamics of the groundwater table (Serrano-Muela et al., 2008; Lana-Renault et al., 2014a), translocation and stemflow processes (Serrano-Muela et al., 2012) and the hydrological properties of their soils (Seeger and Ries, 2008; Regüés et al., 2012, 2017; Serrano-Muela et al., 2014). These findings have enhanced knowledge of the runoff generation processes operating in these catchments under different rainfall and moisture conditions (Lana-Renault et al., 2007, 2014b; Serrano-Muela et al., 2008; Nadal-Romero et al., 2016). These results have also enabled comparisons of their hydrological (García-Ruiz et al., 2008; Lana-Renault et al., 2011; Nadal-Romero et al., 2016) and sedimentological (Nadal-Romero et al., 2012) responses, even under extreme rainfall conditions (Lana-Renault et al., 2014c). The considerable data on meteorological, hydrological and sediment transport variables have been used to test and apply models to simulate soil erosion (Alatorre et al., 2012) and water and sediment yield (López-Vicente et al., 2011) under different land use scenarios, and to better understand the effect of revegetation on the main hydrological processes (Lana-Renault et al., in review). 


\section{Materials and Methods}

\subsection{Production of land use maps}

Land use maps were created for the catchments affected by farmland abandonment (Arnás, Araguás_afforestation and Munilla). Land use maps for pre-abandonment scenarios were produced by interpreting aerial photographs from 1956 (scale 1:32,000) (https://www.iderioja.larioja.org/, http://fototeca.cnig.es/). The aerial photographs of Arnás and Araguás_Afforestation had no geometric correction. The photographs for Arnás were orthorectified using the Leica Photogrammetry Suite (LSP) module of Erdas Imagine 2010, by correcting the stereo-pair images of the area, by the use of 10 geographic control points on an orthophoto taken in 2012 and by 50 tie points. In Araguás_ Afforestation, 15 geographic control points were used to identify the boundary of the sub-catchment, which had been previously defined using an accurate digital elevation model (DEM) and a recent orthophoto. Land use maps for the current post-abandonment scenarios were constructed using 2012 orthophotos (0.5 m spatial resolution) for Arnás and Araguás_afforestation, and 2014 orthophotos ( $0.25 \mathrm{~m}$ spatial resolution) for Munilla. These maps were validated in the field. Map construction involved the use of QGIS 2.18.0-Las Palmas and 2.14.0-Essen and the definition of a common legend for the three catchments.

\subsection{Assessment of changes in hydrological connectivity in the post land abandoned scenarios}

\subsubsection{Index of hydrological connectivity}

Hydrological connectivity is strongly affected by the physical characteristics of a landscape, including its topography, vegetation cover and the presence of man-made elements. In the last decades, models and indices have been developed to simulate and compute hydrological connectivity in relation to the spatial distribution of these factors. These include, for instance, the Network Index (Lane et al., 2009), the Relative Surface Connection (RSC) function (Antoine et al., 2009), and the two-dimensional version of the Connectivity of Runoff Model (Reaney et al., 2014). The index of runoff and sediment connectivity (IC) (Borselli et al., 2008) has been found to determine the potential hydrological connectivity within a landscape based on the physical structure of that landscape. Calculation of the IC requires knowledge of the characteristics of the drainage area and of the flow path. This approach is currently the most widely used around the world, including in Turkey (D'Haen et al., 2013), Japan (Chartin et al., 2017), Australia (Vigiak et al., 2012), Italy (Cavalli et al., 2016), Spain (LópezVicente et al., 2013a, 2017a; Prosdocimi et al., 2017) and Mexico (Ortíz-Rodríguez et al., 2017).

This study used some of the modifications made by Cavalli et al. $(2013,2015)$ to the IC (Borselli et al., 2008), regarding the flow accumulation algorithm and maximum slope threshold. The downslope module $\left(D_{d n}\right)$ considers the probability that runoff and sediment arrive at a defined sink or stream network along the flow path. The upslope 
module $\left(D_{u p}\right)$ summarizes the potential for downward routing of the overland flowproduced upslope and also implements a "stream power"-like approach, taking into account the slope and size of the contributing area:

$$
I C_{K}=\log _{10}\left(\frac{D_{u p, K}}{D_{d n, K}}\right)=\log _{10}\left(\frac{\overline{W_{K}} \cdot \overline{S_{K}} \cdot \sqrt{A_{K}}}{\sum_{i=K, n_{K}} \frac{d_{i}}{W_{i} \cdot S_{i}}}\right)
$$

where $A$ is the upslope contributing area $\left(\mathrm{m}^{2}\right), \bar{W}$ is the average weighing factor of $A$ (dimensionless), $\bar{S}$ is the average slope gradient of $A\left(\mathrm{~m} \mathrm{~m}^{-1}\right), d_{i}$ is the length of the $i$ th cell along the downslope path (m), $W_{i}$ is the weight of the $i$ th cell (dimensionless), and $S_{i}$ is the slope gradient of the $i$ th cell $\left(\mathrm{m} \mathrm{m}^{-1}\right)$. The minimum slope steepness is set at $0.005 \mathrm{~m} \mathrm{~m}^{-1}$ and the maximum slope steepness at $1 \mathrm{~m} \mathrm{~m}^{-1}$. The subscript $K$ indicates that each cell $i$ has its own IC-value. This index is defined in the range of $[-\infty,+\infty]$, with connectivity increasing as IC approaches $+\infty$. The values are relative, site specific and dependent on the computational target (e.g., defined outlet, stream network, lake, dam) and on the spatial resolution of the grid. Thus, absolute output values cannot be compared between different catchments. Consequently, this study focused only on temporal changes in IC in each study catchment.

The weighted flow path length and the factors $\bar{W}, \bar{S}$ and $A$ were calculated using the D-infinity flow accumulation algorithm (Tarboton, 1997) available in the software package $S A G A^{\odot}$ 2.1.2 64 bit, rather than using the D8 single-flow algorithm of the original index. The selection of a suitable algorithm to simulate overland flow processes in hilly landscapes is required for accurate simulations (López-Vicente et al., 2014). The D-infinity approach, along with the TauDEM 5.2 suite tools for the extraction and analysis of hydrologic information from topography (Tarboton, 2013), have been recommended by the European SedAlp research group on sediment transport in mountainous basins (Cavalli et al., 2015). The D-infinity approach has been reported to capture actual real flow paths, especially on hillslopes where divergent flow predominates. Another reason to choose the D-infinity approach was related to DEM resolution. If the cell size is smaller than the width of the channels in the study area, the use of a single-flow algorithm to derive flow accumulation would limit high-drainage areas (i.e. the channel network) to sequences of single cells, thus underestimating channel widths. In contrast, the D-infinity algorithm better approximates channel width by partitioning flow over the entire cross section, resulting in a more representative pattern of IC at catchment and hillslope scales (Martínez-Murillo and López-Vicente, 2017). Finally, the IC model includes the "stream" layer (value 0 in the flow direction map for the streams and 1 for the remaining area), which has been associated with the presence of (semi-)permanent streams (see Appendix A in Borselli et al., 2008). Here, the computed values of IC were linked to the defined stream. 


\subsubsection{Model parameterization}

The $2 \times 2 \mathrm{~m}$ DEM for the Munilla catchment was obtained from the regional government database (https://www.iderioja.larioja.org/). The DEMs for the Arnás and Araguás_Afforestation catchments were generated at a spatial resolution of $2 \mathrm{~m}$ cell size from the available LiDAR data point-cloud provided by the Spanish Geographic Institute (IGN) and the module LAStools of ArcGIS 10.3 that allowed the selection of the points codified as "ground".

Before running IC, the continuity of the flow path lines throughout the hillslope was ensured by using the algorithm of Planchon and Darboux (2001), available in the $S A G A^{\odot}$ 2.1.2 64 bit software package, to remove local depressions of the three DEMs. We considered a minimum slope gradient of $0.01^{\circ}\left(0.00017 \mathrm{~m} \mathrm{~m}^{-1}\right)$, which can be associated with unrealistic sinks or DEM artifacts. The boundaries of the three catchments were automatically calculated by ArcGIS 10.3 upwards from the defined outlets.

The $W$ factor of Eq. (1) was introduced to represent the resistance to water and sediment fluxes due to local properties of the land (soil, vegetation, tillage practices and soil roughness). In the original version of the IC index as well as in other studies, the $W$ factor was equal to the $C-R U S L E$ factor, which represents the vegetation cover and land management. This factor, rather than other landscape factors such as surface roughness (Cavalli et al., 2013) and soil permeability (Gay et al., 2016), was chosen to use as a stable input layer that did not change among the three study areas. Thus, use of the C-RUSLE factor reduced the uncertainties of the IC computations and made their results comparable. The $W$ factor maps were derived from the six vector maps of land uses for previous and current scenarios (see section 3.1). We used the values of the C-RUSLE factor from two catchments of the Pyrenees with vegetation similar to that in our study areas (LópezVicente et al., 2011, 2013b). Values for pine forests at low (early stage of plantation) (De Tar et al., 1980) and high (Miller et al., 2003) elevation, for cereal fields and grasslands (Panagos et al., 2015), and for slots (Schwab et al., 1996) were as described.

\subsection{Collection and analysis of meteorological and hydrological data}

The four catchments were equipped with:

i) several tipping buckets to collect rainfall, installed at different locations in the catchments;

ii) a complete weather station to measure relative air humidity, air temperature, solar radiation and wind velocity;

iii) a gauging station at the outlet, at which the water level in the stream was recorded using an ultrasound and/or pressure sensor. Discharge was determined using established stage discharge rating curves, calibrated by manual discharge measurements. Because the stream channel in the Munilla catchment lies on the bedrock, the water level was directly measured on the bed channel. The cross section of the channel was measured to transform the water level into discharge; and

iv) several piezometers, installed at various distances from the main channel and at different topographical locations, to record the depth of the water table. 
All sensors were connected to dataloggers, which record averaged values every 5 , 10 or 20 minutes, depending on the variable being measured (see table 1). In the San Salvador catchment throughfall and stemflow under forest cover were measured between April 2006 and April 2008 in three areas, each equipped with 25 pluviometers.

This study used existing data on rainfall and streamflow for each catchment. Flood events were identified as increases in discharge exceeding 1.5-times the baseflow discharge prior to the beginning of the rainfall event. Storm-flow was separated from baseflow using the classical graphic method (Hewlett and Hibbert, 1967) and a constant slope of $1.83 \mathrm{l} \mathrm{s}^{-1}$ day $\mathrm{km}^{-2}$, as suggested by Latron et al. (2008). Variables for each flood event included rainfall depth ( $\mathrm{mm})$; maximum rainfall intensity in 5 or $10 \mathrm{~min}$, depending on the catchment $\left(\mathrm{mm} \mathrm{h}^{-1}\right)$; storm-flow coefficient, defined as the ratio of rainfall depth to storm-flow depth; peakflow specific discharge $\left(\mathrm{l} \mathrm{s}^{-1} \mathrm{~km}^{-2}\right)$; baseflow specific discharge at the start of the event $\left(1 \mathrm{~s}^{-1} \mathrm{~km}^{-2}\right)$; and response time (min), defined as the time lag between the centroid of the rainfall and the peakflow discharge.

\section{Results}

\subsection{Land use changes under different post land abandonment scenarios}

Changes in land use in the Munilla, Arnás and Araguás_Afforestation catchments are shown in Figures 2 and 3. In 1956, the cultivated areas differed notably among these three catchments. Araguás_Afforestation was almost completely (87\%) covered by cereal crops and pastures; in Munilla, cereal crops on terraced fields represented $36 \%$ of the catchment area and were mainly located in the lower part of the catchment; whereas in Arnás, the cultivated area was very small (7\%) and mostly located on the valley bottom, indicating that land abandonment in this catchment occurred earlier. However, in Arnás, the low density cover of the vegetation on the abandoned fields and the clear limits of the fields observed in the aerial photographs suggest an early stage in the vegetation succession process (Molinillo et al., 1997). In Araguás_afforestation, the small non-cultivated area was occupied by open forest $(2 \%)$ and shrubs $(6 \%)$ and was spread throughout the catchment. Flysch outcrops occupied $3 \%$ of the catchment area and were located close to the main stream. In Munilla, 55\% of the surface that was not cultivated, mostly the higher part of the catchment, was occupied with shrubs, while 5\% was occupied by bedrock (mainly sandstone) outcrops.

At present, cultivated areas occupy less than $2 \%$ of both the Araguás_afforestation and Munilla catchments, with pastures occupying 7\% of the Arnás catchment. However, the evolution of the abandoned land has differed widely among these catchments. In Arnás, large areas of dispersed shrubs have evolved into dense shrubs and forest, especially on the northfacing slopes, resulting in the shrinkage of bare surface area from $2 \%$ to $0.5 \%$. A trail was built to connect small lots that are still used as well as the neighboring western catchment. In Araguás_Afforestation, 59\% of the former agricultural land was replaced in the late 1960s by afforested $P$. sylvestris on the southwest-facing slope and $P$. nigra on the southeast-facing slope. As a result of farmland abandonment, the areas covered by shrubs and forest in 1956 have increased, currently each occupying $16 \%$ of the catchment. This natural vegetation is mainly 
located in the lower part of the catchment and in some sectors close to the divide. The outcrop area has slightly increased (4\%), as has the area occupied by bare soil (from $0.1 \%$ to $2 \%$ ). These bare areas are spread throughout the catchment, with more on the east-facing slope. New forest roads and trails were built during afforestation. In Munilla, the cultivated terraces have been replaced with shrubs, with a higher density cover on the shady aspects. The upper area of the catchment, already covered by shrubs in 1956, has evolved into a denser cover or has been replaced at some locations by patches of afforested P. nigra (7\%). These trees, of average height 2-3 m, do not yet constitute a well-developed cover. New forest roads and trails were built during afforestation and to connect to the hamlet of San Vicente de Munilla, located in the western part of the catchment. The main channels are flanked by riparian forest, which has slightly increased in area during this period, currently occupying $3 \%$ of the catchment.

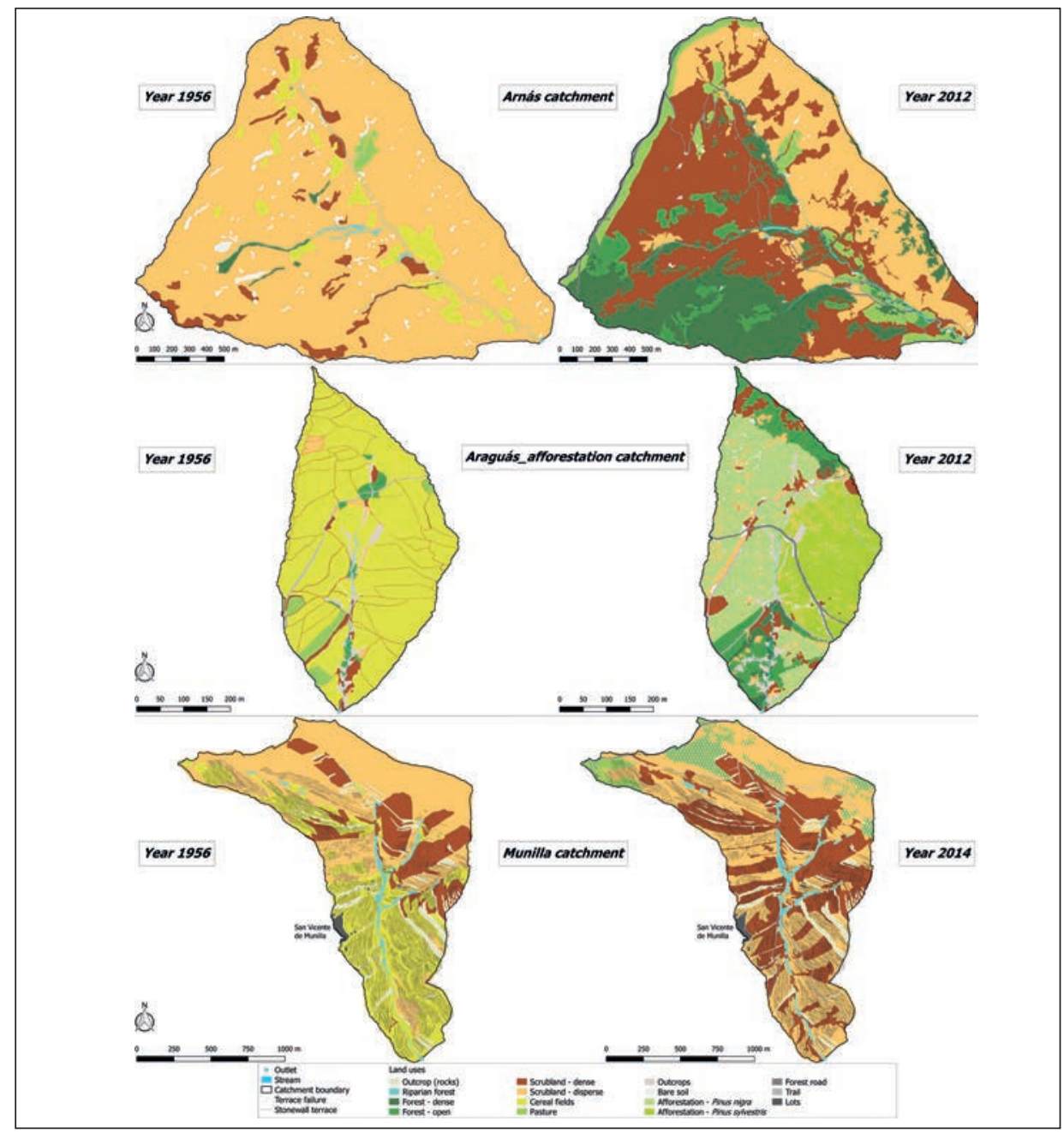

Figure 2. Maps of past and present land uses in the three abandoned catchments. Note that the scales of the maps are different. 


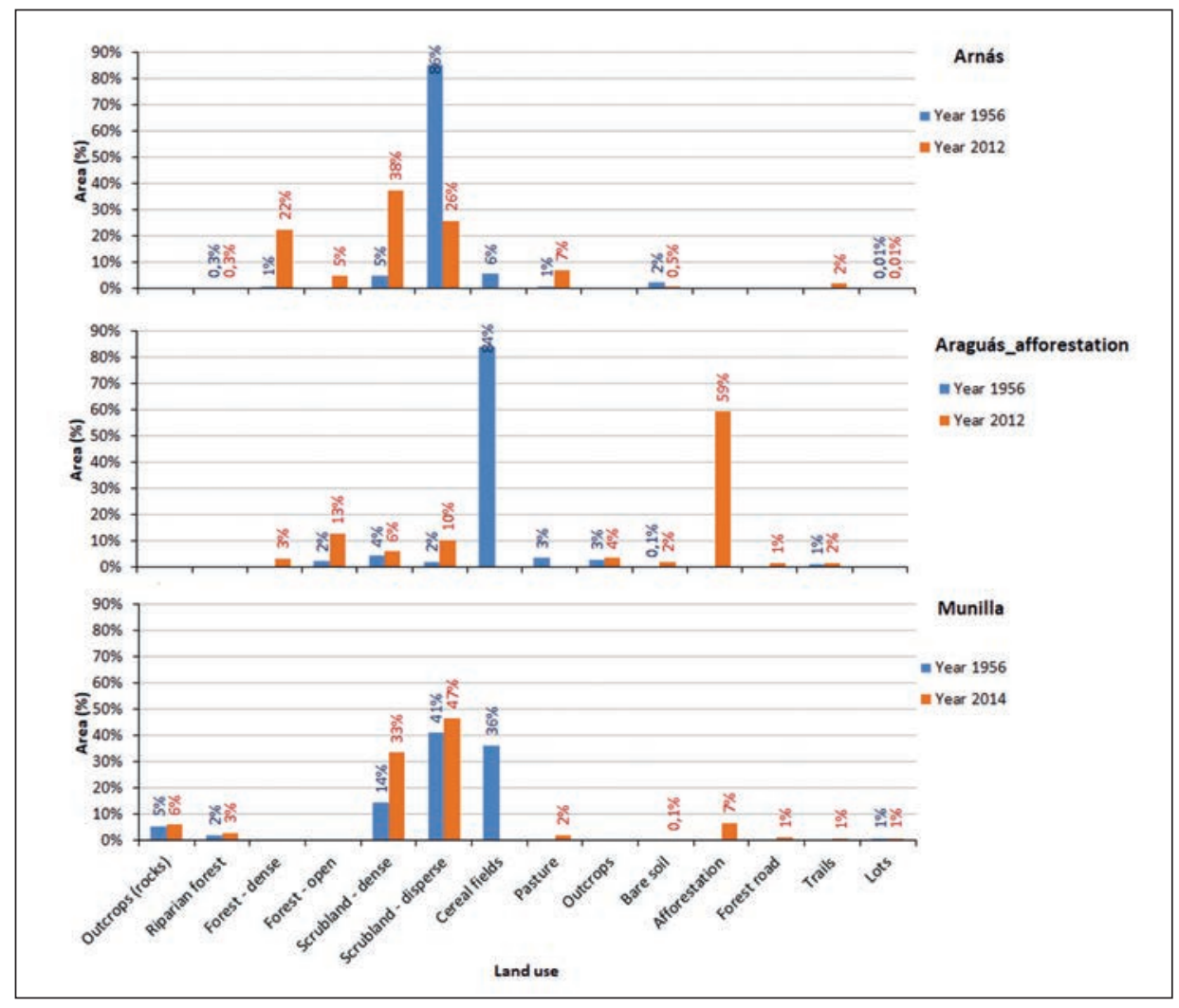

Figure 3. Land use evolution in the three abandoned catchments.

\subsection{Changes in hydrological connectivity during different post farmland abandonment scenarios}

The IC was applied to the previous and current scenarios in Arnás, Arguás Afforestation and Munilla (Figs. 4, 5 and 6). In the three post farmland abandonment scenarios, hydrological connectivity decreased, especially in the afforested scenario, with a reduction of $55.3 \%$ (Table 2). In 1956, the Araguás_Afforestation catchment was heavily cultivated, with most of the catchment having relatively high IC values. Afforestation of a large portion of the catchment resulted in an overall decrease in connectivity, but this decrease was less pronounced in the lower parts.

In the Arnás catchment, the reduction was lower (28.1\%), in part because the past scenario was already dominated by shrubs, so the changes in vegetation cover were not very substantial. Table 2 shows that the reduction of the C-RUSLE factor was lower in this catchment (-55.3\%) than in Araguás_Afforestation (-69.9\%). In 1956 there was a clear contrast between the southwestern- and northeastern-facing slopes. The former, much steeper and with a shorter drainage network, showed higher IC values, whereas the gentler north-facing slope, with a longer drainage network, had lower IC values. 
Farmland abandonment resulted in an overall reduction in hydrological connectivity, which was much more evident on the northeastern-facing slope, where the recovery of vegetation has been greater.

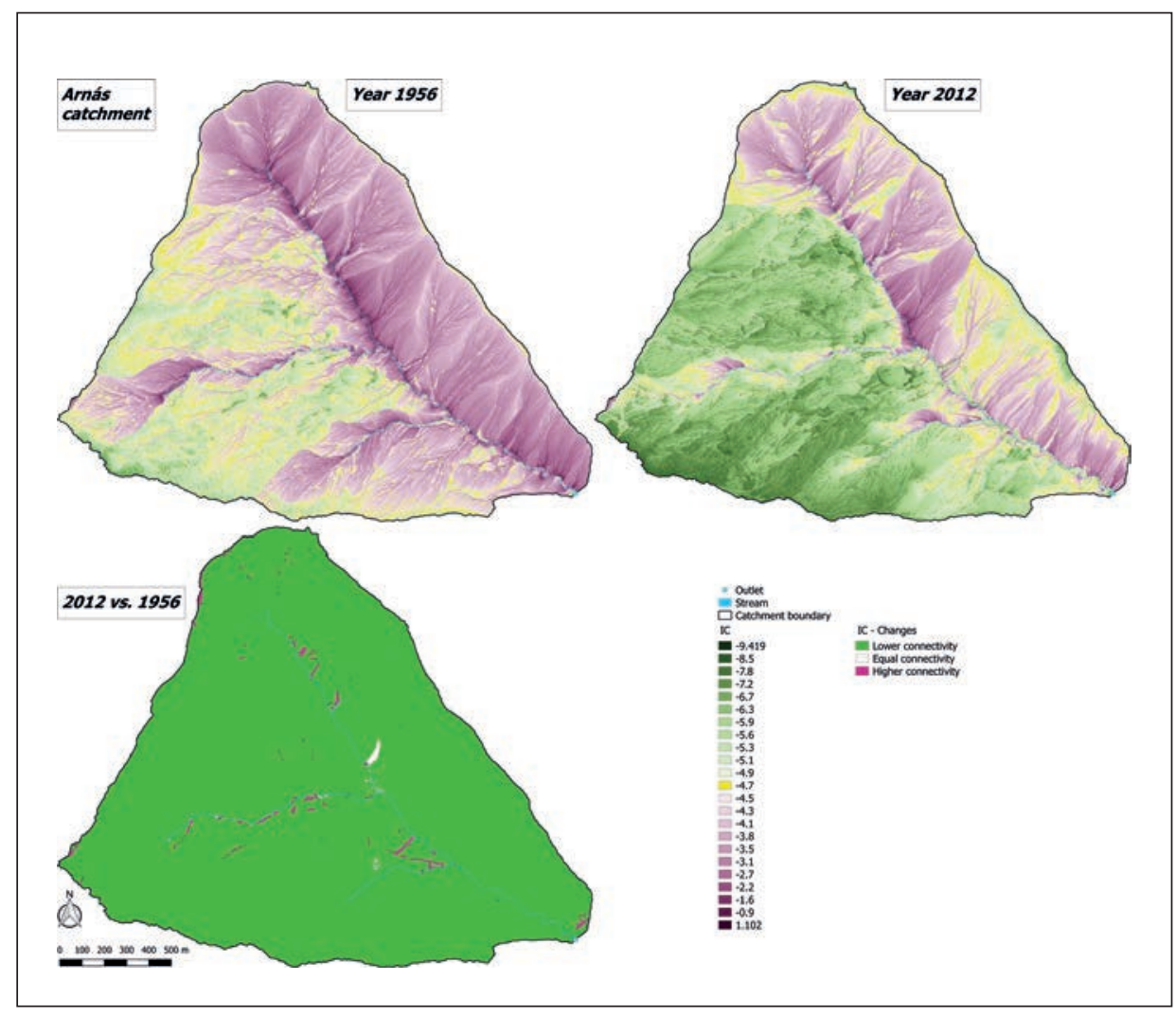

Figure 4. Index of connectivity (IC) for past and present scenarios in Arnás catchment (upper panel) and changes in IC during that period (lower panel).

In the bench-terraced catchment (Munilla), the cultivated area in 1956 had relatively high IC values, except for areas located in the upper-western part of the catchment. Interestingly, similar IC values were observed in cultivated areas on the lower part and some non-terraced slopes covered by shrubs on the upper part, suggesting that the terraced topography had a counteracting effect on connectivity. Overall, farmland abandonment decreased hydrological connectivity, especially in formerly cultivated fields. However, this trend was much lower than in the other catchments, with a reduction of only $7.7 \%$. The low decrease in Munilla resulted from the absence of trees and denser vegetation, which was partly due to cattle grazing (the reduction of the C-RUSLE factor was $-24.2 \%$, the lowest of the three scenarios), and to the fact that this catchment was still dominated by a terraced topography. 


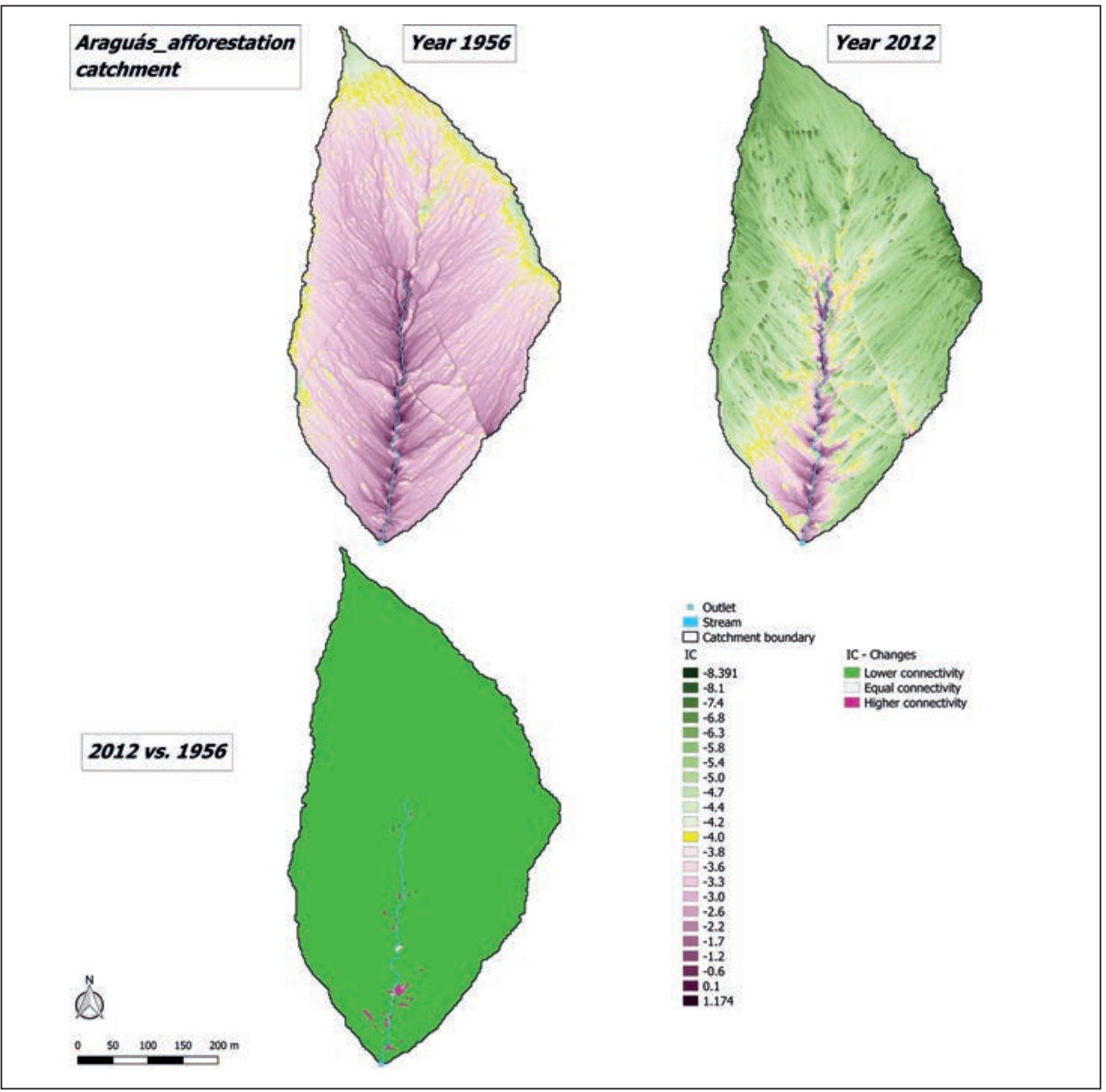

Figure 5. Index of connectivity (IC) for past and present scenarios in Araguás_Afforestation catchment (upper panel) and changes in IC during that period (lower panel).

Table 2. Estimated values and changes in hydrological connectivity index (IC) at the catchment scale in the three abandoned areas. The mean values of the $C$-RUSLE factor are included.

\begin{tabular}{|l|r|r|r|r|r|r|r|r|r|}
\hline IC & \multicolumn{4}{|c|}{ Arnás } & \multicolumn{3}{c|}{ Araguás_Afforestation } & \multicolumn{3}{c|}{ Munilla } \\
\hline Value & $\mathbf{1 9 5 6}$ & \multicolumn{1}{|c|}{$\mathbf{2 0 1 2}$} & $\boldsymbol{\Delta}(\boldsymbol{\%})$ & $\mathbf{1 9 5 6}$ & \multicolumn{1}{|c|}{$\mathbf{2 0 1 2}$} & $\boldsymbol{\Delta}(\boldsymbol{\%})$ & $\mathbf{1 9 5 6}$ & $\mathbf{2 0 1 4}$ & $\boldsymbol{\Delta}(\boldsymbol{\%})$ \\
\hline Min & -8.332 & -9.418 & -13.0 & -5.841 & -8.391 & -43.7 & -8.273 & -8.554 & -3.4 \\
Mean & -4.100 & -5.252 & -28.1 & -3.167 & -4.920 & -55.3 & -4.282 & -4.611 & -7.7 \\
Max & 1.102 & 0.747 & -32.2 & 1.173 & 0.647 & -44.8 & 1.851 & 1.731 & -6.5 \\
Sd & 0.889 & 1.209 & 36.0 & 0.691 & 0.999 & 44.6 & 0.969 & 0.918 & -5.3 \\
Cv & -0.217 & -0.230 & 6.2 & -0.218 & -0.203 & -6.9 & -0.226 & -0.199 & -12.0 \\
C-RUSLE (mean) & 0.224 & 0.100 & -55.3 & 0.272 & 0.082 & -69.9 & 0.256 & 0.194 & -24.4 \\
\hline
\end{tabular}


Table 3 shows the surfaces of catchments that experienced reductions, increases, and no change in connectivity. Most $(\approx 99 \%)$ of the area in Arnás and Araguás_Afforestation showed reductions in connectivity. Although $87.7 \%$ of Munilla showed also reductions in connectivity, $11.6 \%$ showed higher connectivity, with some of these areas located upstream of terraced wall collapses (see inset in Fig. 6) caused by land abandonment. Other areas of increased connectivity included those in the upper part of the catchment, below some sectors of forest roads and trails, and a sector in which the dense shrub cover was replaced by incipient afforested trees. In Arnás and Araguás_Afforestation, most small areas with higher connectivity are located close to the main stream. In Araguás_ Afforestation, these areas correspond to the flysch outcrops. In Arnás, some of these areas are associated with the construction of a new forest road or with small areas of bare soil. The slight changes in IC observed in some areas may be explained by the spatial distribution of changes in vegetation and the computational procedure used to calculate the index.

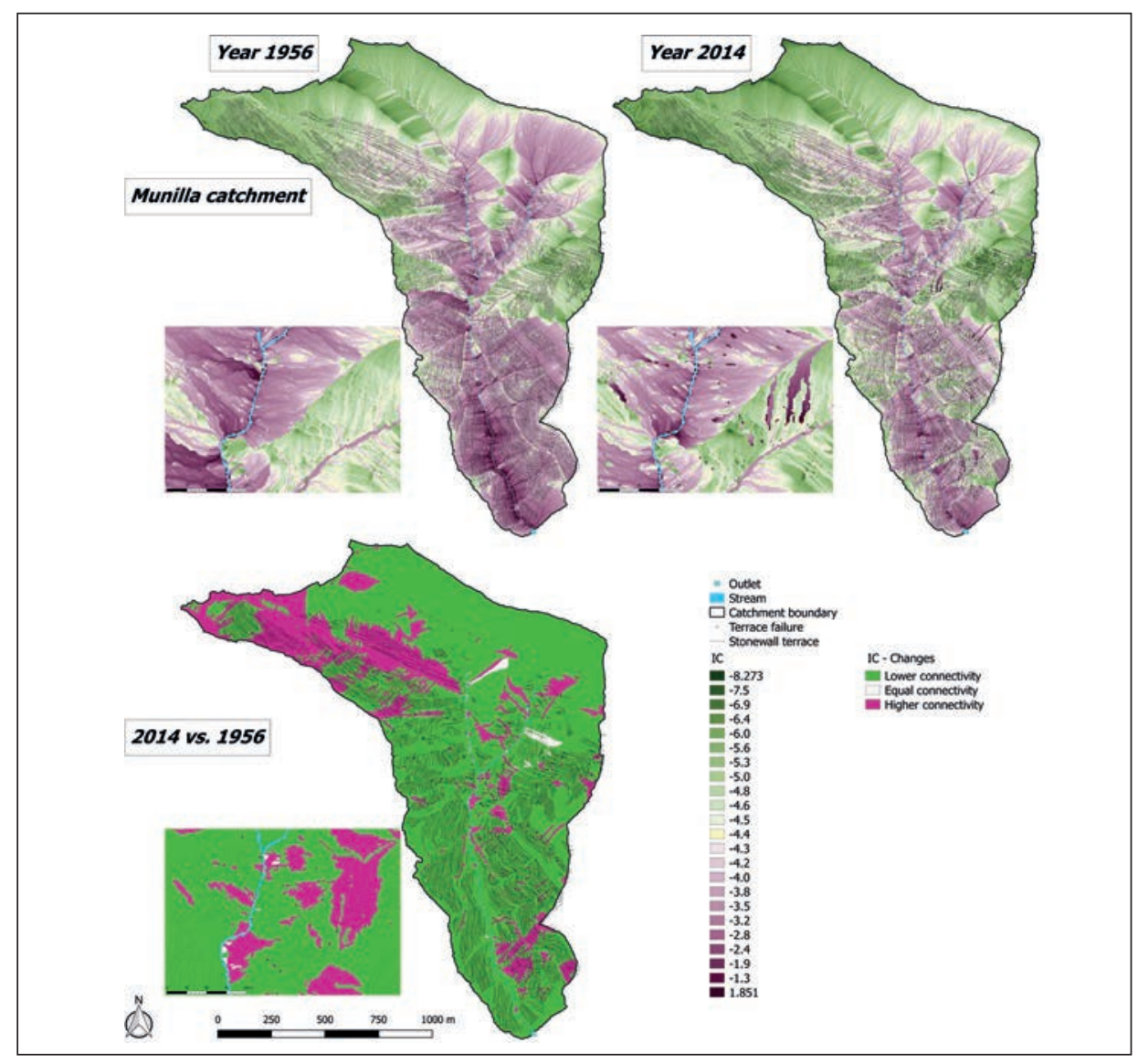

Figure 6. Index of connectivity (IC) for past and present scenarios in Munilla catchment (upper panel) and changes in IC during that period (lower panel). 
Table 3. Percent surfaces of the abandoned catchments with hydrological connectivity index (IC) in 2014 lower, equal and higher relative to the estimated IC in 1956.

\begin{tabular}{|l|c|c|c|}
\hline$\Delta$ IC (2014 vs. 1956) & Arnás & Araguás_Afforestation & Munilla \\
\hline Lower IC & $99.3 \%$ & $99.6 \%$ & $87.7 \%$ \\
Equal IC & $0.2 \%$ & $0.1 \%$ & $0.7 \%$ \\
Higher IC & $0.5 \%$ & $0.3 \%$ & $11.6 \%$ \\
\hline
\end{tabular}

\subsection{Hydrological responses to rainstorm events under different post farmland abandon- ment scenarios and natural forest}

Some hydrological differences among the Arnás, Araguás_Afforestation and San Salvador catchments have been identified in previous work (García-Ruiz et al., 2000, 2008; Lana-Renault et al., 2007, 2011; Serrano-Muela et al., 2008; Nadal-Romero et al., 2016). These studies showed that Arnás and Araguás_Afforestation were able to generate runoff over the entire year, with the highest floods recorded in winter and spring and a lower response during dry summer conditions. In San Salvador, late winter and spring were the only high flow periods, with little or no response during summer and autumn. As a result, the Arnás and Araguás_Afforestation catchments recorded more than twice the number of floods per year as San Salvador. Differences were also observed in the hydrographs characteristics of the events. Relative to the forested catchment, peakflows in Arnás and Araguás_Afforestation were generally higher, response times faster and recession limbs shorter. In Munilla, runoff was concentrated between late winter and spring, with few floods recorded during the summer (Lana-Renault et al., 2014b; Llorente-Adán et al., 2015). Flood hydrographs were usually gentle, with slow responses and long recession limbs.

In all four catchments, storm-flow was most closely associated with previous moisture conditions (i.e. the baseflow at the start of the flood event and antecedent rainfall) (Lana-Renault et al., 2007; García-Ruiz et al., 2008; Llorente-Adán et al., 2015; Nadal-Romero et al., 2016) (table 4). This was confirmed in Arnás and San Salvador by Lana-Renault et al. (2014a) and Serrano-Muela et al. (2008), who showed that streamflow discharge in these catchments was strongly related to the dynamics of the water table. Rainfall in Arnás and Araguás_Afforestation also influenced the stormflow, but to a lesser extent than preceding moisture conditions. Important differences in the variability of peakflow discharge were observed among these catchments. In Arnás, peakflow discharge was mainly related to rainfall and rainfall intensity; whereas in Araguás_Afforestation, Munilla and San Salvador, peakflow discharge was associated only with preceding moisture conditions (Lana-Renault et al., 2007; García-Ruiz et al., 2008; Llorente-Adán et al., 2015; Nadal-Romero et al., 2016).

Table 4. Factors associated with storm-flow and peak discharge in the study catchments. P: rainfall; IP: rainfall intensity; AMC: antecedent moisture conditions (i.e. the baseflow at the start of the flood event and antecedent rainfall)

\begin{tabular}{|l|c|c|c|c|}
\hline & Arnás & Araguás_Afforestation & Munilla & San Salvador \\
\hline Storm-flow & AMC, P & AMC, P & AMC & AMC \\
\hline Peakflow discharge & P, IP & AMC & AMC & AMC \\
\hline
\end{tabular}


The differences in hydrological responses for the different post land abandonment scenarios and the natural forest are illustrated in Figures 7 and 8, which show selected hydrographs for each study catchment under dry and wet conditions, respectively. A large $(\mathrm{P} \approx 30-40 \mathrm{~mm})$ and intense rainfall event under dry conditions (Fig. 7) produced the highest response in Arnás, with a runoff coefficient of 0.18 and a peakflow specific discharge of $532 \mathrm{~s}^{-1} \mathrm{~km}^{-2}$. The responses in Araguás_Afforestation and San Salvador were much lower, with runoff coefficients of 0.04 and 0.05 , respectively. Interestingly, peakflow specific discharge in Araguás_Afforestation was more than double than that in San Salvador (94 vs. $361 \mathrm{~s}^{-1} \mathrm{~km}^{-2}$ ). Under such conditions, very little hydrological response was observed in Munilla, with a runoff coefficient below 0.01 and a peakflow specific discharge of $11 \mathrm{l} \mathrm{s}^{-1} \mathrm{~km}^{-2}$. In the three abandoned catchments, the hydrological responses were rapid ( $<65 \mathrm{~min})$ and the recessions were short (55-85 $\mathrm{min})$, whereas in the natural forest the responses were slower (about $4 \mathrm{~h}, 30 \mathrm{~min}$ ) and the recession much longer (about $14 \mathrm{~h}$ ).

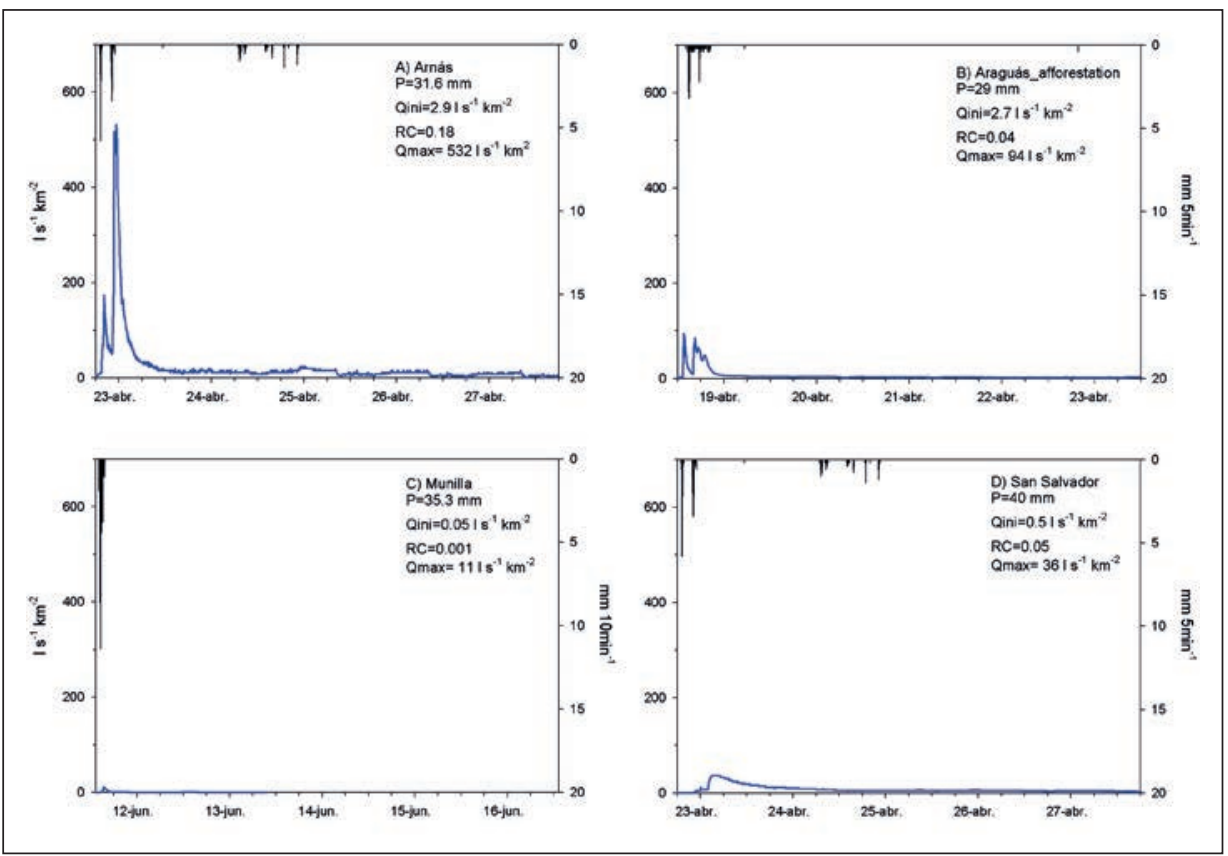

Figure 7. Hydrographs of a) Arnás (22/04/2005), b) Araguás_Afforestation (18/04/2015), c) Munilla (11/06/2014) and d) San Salvador (22/04/2005) catchments for similar rainfall $(P)$ characteristics under dry conditions. Qini: baseflow discharge at the start of the event; RC: runoff coefficient; Qmax: peakflow. Note that in Munilla rainfall is reported as $\mathrm{mm} 10 \mathrm{~min}^{-1}$.

A moderate $(\mathrm{P}=16-19 \mathrm{~mm})$ and low intensity rainfall event under wet conditions (Fig. 8) produced a similar streamflow response in both Arnás and Araguás_Afforestation, with runoff coefficients of 0.33 and 0.27 , respectively, and peakflow specific discharges of $3261 \mathrm{~s}^{-1} \mathrm{~km}^{-2}$ and $2691 \mathrm{~s} \mathrm{~s}^{-1} \mathrm{~km}^{-2}$, respectively. The response times in Arnás and Araguás Afforestation were $3 \mathrm{~h}$ and almost $4 \mathrm{~h}$, respectively, and the recessions in both catchments 
were slightly less than $3 \mathrm{~h}$. San Salvador was characterized by a moderate response (runoff coefficient 0.22 ), a much gentler peakflow specific discharge $\left(77 \mathrm{l} \mathrm{s}^{-1} \mathrm{~km}^{-2}\right)$, a much slower response $(7 \mathrm{~h})$ and a very long recession ( $>5$ days). The hydrological response in Munilla was the lowest, with a runoff coefficient of 0.12 and a peakflow specific discharge of $33 \mathrm{l} \mathrm{s}^{-1} \mathrm{~km}^{-2}$. Response time was similar to that in San Salvador (about $9 \mathrm{~h}$ ) and the recession also was very long ( $>2$ days).

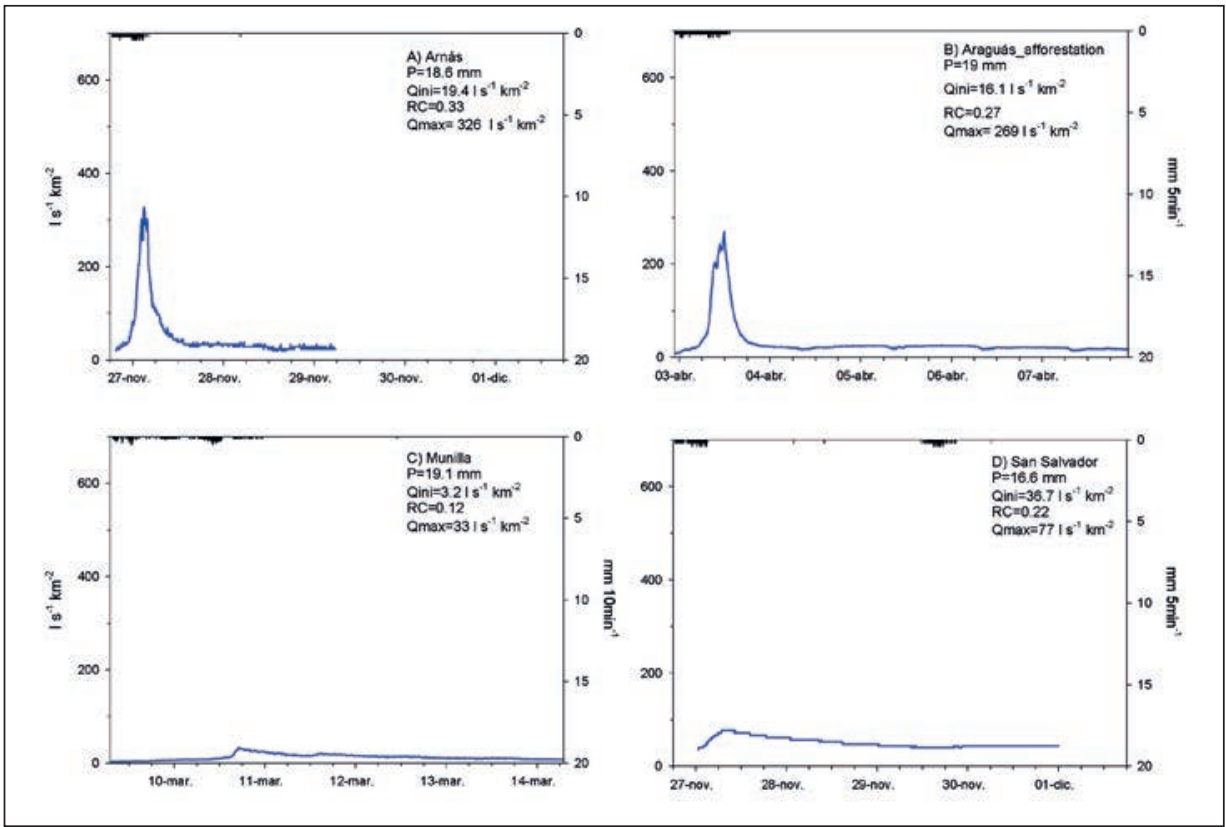

Figure 8. Hydrographs of a) Arnás (26/11/2000), b) Araguás_Afforestation (03/04/2014), c) Munilla (09/03/2016) and d) San Salvador (26/11/2000) catchments for similar rainfall ( $P$ ) characteristics under wet conditions. Qini: baseflow discharge at the start of the event; $R C$ : runoff coefficient; Qmax: peakflow. Note that in Munilla rainfall is reported as $\mathrm{mm} 10 \mathrm{~min}^{-1}$.

\section{Discussion}

In the Mediterranean region, widespread farmland abandonment began in the 1950s and continued through to the 1970s (Lasanta et al., 2017a). This abandonment period, which began later than in most western European countries, coincided with a period of industrialization and population migration to cities. Vegetation expansion on abandoned fields is usually a complex process and depends on multiple natural and human-induced factors, including the time since abandonment, the climatic conditions, the topography (mainly the slope gradient and aspect), the soil quality after abandonment (Romero-Díaz et al., 2017), the type of fields (i.e., sloping or terraced fields) and land management following abandonment (García-Ruiz and Lana-Renault, 2011). Thus, abandoned land scenarios can vary widely, as was observed in the three 
studied catchments. Because of its lower accessibility, most of the Arnás catchment had already been abandoned in the 1950s. After almost 70 years, this catchment is a mosaic of shrubs (64\%) and forest (27\%) at different stages of succession, largely dependent on the topography and soil characteristics (Navas et al., 2008). A forested area developed easily on the more humid and gentler northeastern-facing aspect, whereas shrubs still dominate on the steeper southwestern-facing slope, which has thinner and poorer soils. The permanence of shrubs (in particular, G. scorpius) has been observed elsewhere in the Central Pyrenees (Lasanta et al., 2017c) and has been associated with soil degradation resulting from decades of shifting agriculture. The Araguás Afforestation catchment, closer to the town of Jaca, was cultivated for a longer period of time but was extensively afforested by the national forest services in the 1960s to limit soil erosion in abandoned lands. At present, $75 \%$ of the catchment is covered by forest, most of it planted artificially, and $16 \%$ is covered by shrubs. The expansion of vegetation on former agricultural land has been widely documented in the Pyrenees. For example, the area of the neighboring Aísa valley occupied by arable land in 1956 was already small (10\%), decreasing to 5\% in 2000 (Lasanta-Martínez et al., 2005). Forest cover doubled between 1957 and 2000, with 54\% of the study area covered by forest in 2000. A similar evolution was observed in the Eastern Pyrenees, with the small Cal Rodó catchment experiencing, between 1956 and 1996, a decrease in grasslands and crops from $28 \%$ to $18 \%$ and an increase in forest area from $40 \%$ to 64\% (Poyatos et al., 2003). Farmland abandonment occurred a few years later in the Iberian Range than in the Pyrenees. In 1956, 38\% of the Camero Viejo region was cultivated, consisting mostly of terraced fields (Arnáez et al., 2011). Forty-five years later, however, the amount of arable land had dramatically decreased, to only $2 \%$ of the entire study area. During this period, the percentage occupied by forest increased from $10 \%$ to $37 \%$, including both natural and afforested trees. At the same time, abandoned land has been used for extensive cattle grazing, greatly retarding the transition from shrubs to forest (Tzanopoulos et al., 2007; García-Ruiz and Lana-Renault, 2011). The Munilla catchment is a good example of land use evolution in this area, with $80 \%$ of the catchment covered by shrubs, and $7 \%$ afforested. The areas covered by shrubs represent formerly cultivated terraces currently grazed by cattle. Although vegetation tends to expand in the three study catchments, our findings suggest that the evolution of land cover on abandoned farmland varies widely, resulting in diverse post land abandonment scenarios, with differing hydrological implications. Moreover, the dominance of shrub cover in some of the study catchments suggests that forest can still expand in the near future (Verburg and Overmars, 2009; Lasanta et al., 2017a), making the forecast of water resources challenging.

Changes in computed hydrological connectivity using a modified version of Borselli's index differed among the study catchments. This index, which represents the potential connection of a local part of a catchment to the fluvial network based on surface characteristics, was strongly influenced by land cover, as we considered vegetation as a key factor influencing connectivity due to its capacity to brake overland flow velocity and thereby trap sediment (through deposition) and water (through infiltration) fluxes (Puigdefábregas, 2005; Sandercock and Hooke, 2011). Our results showed that farmland 
abandonment decreases connectivity due to the growth of vegetation. The largest decrease was observed in Araguás_Afforestation due to the dramatic change from crop fields to tree cover in almost the entire catchment, and the lowest decrease was observed in Munilla, where the development of denser vegetation has been constraint by cattle grazing and the topography is dominated by terraced hillslopes. Decreases in connectivity following land abandonment due to vegetation recovery have been reported before. In southeastern Spain, for example, a $76 \%$ reduction in catchment connectivity, due to farmland abandonment and afforestation practices, was estimated between 1956 and 2006 (Quiñonero-Rubio et al., 2013). Similarly, a decrease in connectivity in the central part of the Ebro basin was found to be directly related to a $71 \%$ decrease in agricultural land between 1957 and 2010 (Lizaga et al., 2016). Revegetation of former grazing areas in the subalpine belt of the Central Pyrenees was found to lead to morphological changes in the river channel (incision and development of a terrace level) and to a subsequent reduction in connectivity between the slopes and the channel (Sanjuán et al., 2016).

Farmland abandonment also involves the introduction of new landscape elements (e.g., forest roads and trails associated to afforestation practices) and the appearance of new hydrogeomorphological processes, such as terrace wall failures that increase connectivity. Evaluations of small afforested catchments in Japan (López-Vicente et al., 2017b) and small agricultural and vegetated catchments in southeastern Spain (Marchamalo et al., 2016) showed that trails have a major influence on hydrological and sediment connectivity, as they favor runoff concentration (Croke et al., 2005) and lateral connections between different hillslope sections. Recent studies in the Mediterranean region (Ore and Bruins, 2012; Calsamiglia et al., 2017) have demonstrated the efficiency of agricultural terraces in promoting disconnectivity between the slopes and channels. However, abandonment of these terraces can generate concentrated runoff and sediment flows along preferential pathways created by the successive collapse of several terraces, promoting connections between these pathways and the main stream network (Calsamiglia et al., 2017). Changes in connectivity can explain changes in catchment runoff response and sediment yield (Meerkerk et al., 2009; López-Vicente et al., 2013a; Dung et al., 2015). Thus, a general decrease in connectivity is expected to reduce streamflow and sediment discharge. However, we have shown that, despite the overall reduction in connectivity at the catchment scale, higher connectivity has been observed in some areas after land abandonment. Identifying these areas is essential as they indicate "hot spots" where (severe) soil erosion and sediment delivery to the channel may occur.

Significant differences were observed in the hydrographs of selected flood events in the four study areas under similar rainfall and moisture conditions. Under both dry and wet conditions, Arnás produced the greatest runoff and the highest peakflows. It was the only scenario that recorded a notable hydrological response under dry conditions, suggesting that a large part of the catchment was able to contribute to streamflow under such conditions, especially in response to high intensity rainfalls. Lana-Renault et al. (2007) already demonstrated that under such conditions, infiltration excess runoff over areas with sparse vegetation and low permeability soils occurred in this catchment. Similar findings have been observed in the Mediterranean region, where rainfall can be 
very intense and soils may be degraded (Martínez-Mena et al., 1998; Latron and Gallart, 2007).

The runoff production in the Araguás_Afforestation catchment was somehow similar to that of a naturally forested catchment, with lower values under dry conditions and moderate-to-high values under wet conditions. These findings demonstrate the effects of trees on rainfall interception and evapotranspiration processes. However, Nadal-Romero et al. (2016) showed that very intense rainfall events could produce much higher runoff coefficients in the afforested catchment compared with the natural forest. Another interesting point is that Araguás_Afforestation and San Salvador showed completely different hydrograph characteristics. Much higher peakflows were observed in Araguás_Afforestation, which, under wet conditions, may be comparable to the peakflow generated in Arnás. Under such conditions, the hydrographs were characterized by rapid responses and short recession limbs in both catchments, Arnás and Araguás_Afforestation, findings usually associated with excess saturation overland flow favored by soils with low storage capacity (e.g., shallow soils) that saturate easily (Burch et al., 1987; Combes et al., 1994). The occurrence of these processes is supported by the correlation between storm-flow discharge and rainfall in these catchments. Thus, although they differ significantly in vegetation cover, the soil properties of Arnás and Araguás_Afforestation are similar and result from intense agricultural practices in the past, a finding that may explain their similar hydrological responses under wet conditions. This is in accordance to Hümann et al. (2011) who showed, in Southwest Germany, that soils under afforestation still possessed hydrological properties of the former agricultural land. The effect of the vegetation cover is evident under dry conditions, with much lower values of runoff in Araguás_Afforestation than in Arnás, even in response to a high intensity rainfall event $\left(>30 \mathrm{~mm} \mathrm{~h}^{-1}\right)$. The rapid hydrological responses in both catchments under such conditions suggest the occurrence of overland flow processes, probably resulting from excess infiltration runoff in areas devoid of vegetation well connected to the main channel. In Arnás, the larger runoff coefficient and the good relationship between peakflow discharge and rainfall intensity indicate the important contribution of the infiltration excess runoff processes to the streamflow response, which may involve a relatively large area of the catchment, e.g., over localized sectors of the better connected south-facing slope, with sparse shrub cover and degraded soils (Navas et al., 2008; Butzen et al., 2011).

The lowest runoff and peak flows under both dry and wet conditions were observed in Munilla, which may be due, at least in part, to the location of this catchment in a drier climate than that of the Pyrenean catchments. Under dry conditions, the extremely low runoff coefficient and short response time and recession indicate that only the channel itself and neighboring areas contributed to the streamflow. Under wet conditions, runoff was low to moderate, with a slow response to rainfall and a very long recession, comparable to that of the forest catchment. Slow responses and long recession limbs usually indicate a large contribution of subsurface flows (Whipkey, 1965; Burch et al., 1987; Palleiro et al., 2014), favored by thick and well developed soils, both of which are found in the terraces and the natural forest catchments. Although relatively little is known about hydrological processes in terraced catchments, water flow within soils 
was shown to be important (Gallart et al., 1994; Camera et al., 2014; Nunes et al., 2016; Petri et al., 2017). Thus, despite the Munilla and San Salvador catchments having completely different vegetation covers (sparse shrubs and dense forest, respectively), their hydrological responses are somehow similar, perhaps due to similarities in their soil properties. The importance of soil water storage in these two catchments was evidenced by studies showing that hydrological responses correlated only with antecedent moisture conditions (García-Ruiz et al., 2008; Serrano et al., 2008; Llorente-Adán et al., 2015).

As a final remark we can say that this study used a static index to assess potential hydrological and sediment connectivity through overland flow, as this is the mechanism by which sediment is transferred through a catchment. However, we found that, in some land abandonment scenarios, runoff response can be largely generated by subsurface flows. Thus, assessing the occurrence and extent of surface flow in these scenarios is a key to better evaluating actual changes in surface water and sediment transfer paths. On the other hand, the parametrization of the hydrological index was greatly determined by the land cover. Our results suggest, however, that soils characteristics play an essential role in the hydrological behavior of the studied environments. Thus, alternative methods for evaluating hydrological connectivity are required, which include soil properties or the assessments of IC for different targets (e.g., ephemeral gullies, sinks or springs).

\section{Conclusions}

Farmland abandonment has affected large areas of mountainous regions, resulting in dramatic changes in the landscape and important environmental consequences. The evolution of land uses in three small catchments monitored by the Instituto Pirenaico de Ecología (CSIC) and the University of La Rioja in northern Spain illustrates the complexity of the post land abandonment process, which depends on a variety of natural and human-induced factors. One catchment (Arnás) was left to undergo a process of natural recolonization and is at present covered with dense forest and shrubs on its northfacing slope and sparse shrubs on its south-facing slope, which has thinner and poorer soils. Another catchment (Araguás_Afforestation) was afforested in the 1960s, with most of its surface currently covered by forest, mostly pines of moderate size. In the third catchment (Munilla), cultivated with terraced fields in the past, vegetation recovery has been partly restricted by the introduction of extensive cattle grazing, with this catchment at present mostly covered by shrubs. Computed hydrological connectivity decreased at the catchment scale following land abandonment but increased in localized areas close to the main channel, new forest roads and trails, and upstream of terrace wall collapses. Significant differences were observed in the hydrological responses of the three post land abandonment scenarios and a natural forest scenario (represented by a fourth catchment), showing that both vegetation cover and soil properties can influence runoff generation processes. Arnás, dominated by shrubs and with degraded soils in a large part of the catchment, was able to produce significant storm-flow discharge over the entire year, even under dry conditions, with high peakflows and fast responses. Araguás_Afforestation, covered by trees, produced lower storm-flow discharge under dry conditions; however, once the soils were wet, the hydrological response was moderate-to-high and characterized by high 
peakflow. Interestingly, the flood hydrographs in this catchment, characterized by rapid responses and short recessions, differed greatly from the gentler hydrographs of a natural forest. Munilla, dominated by shrubs on terraced fields, had the lowest hydrological response, with long response times and recessions. These results suggest that land and water management should pay attention to the large heterogeneity of post farmland abandonment scenarios when assessing the hydrological implication of farmland abandonment and establishing restoration measures to mitigate soil erosion.

\section{Acknowledgements}

This study was performed under the framework of the European COST action ES1306 "Connecteur" (Connecting European Connectivity Research) and received financial support from Project ESPAS (CGL2015-65569-R), funded by the Spanish Ministry of Economy and Competitiveness and FEDER. Manuel López-Vicente and Estela NadalRomero were beneficiaries of "Proyecto de I+D+i para Jóvenes Investigadores" and "Ramón y Cajal" postdoctoral contracts, respectively, both from the Spanish Ministry of Economy and Competitiveness. The authors would like to thank the municipality of Munilla who permitted and helped with the installation of field equipment. The authors also thank J. Latron, F. Gallart, P. Llorens and J. Estrany for their help with field instrumentation in the Munilla catchment.

\section{References}

Alatorre, L.C., Beguería, B., Lana-Renault, N., Navas, A., García-Ruiz, J.M. 2012. Soil erosion and sediment delivery in a mountain catchment under scenarios of land use change using a spatially distributed numerical model. Hydrological and Earth Sciences Systems 16, 13211334. https://doi.org/10.5194/hess-16-1321-2012.

Antoine, M., Javaux, M., Bielders, C. 2009. What indicators can capture runoff-relevant connectivity properties of the microtopography at the plot scale? Advances in Water Resources 32 (8), 1297-1310. https://doi.org/10.1016/j.advwatres.2009.05.006.

Arnáez, J., Lasanta, T., Errea, M.P., Ortigosa, L. 2011. Land abandonment, landscape evolution, and soil erosion in a Spanish Mediterranean mountain region: the case of Camero Viejo. Land Degradation \& Development 22, 537-550. https://doi.org/ 10.1002/ldr.1032.

Arnáez, J., Lana-Renault, N., Lasanta, T., Ruiz-Flaño, P., Castroviejo, J. 2015. Effects of farming terraces on hydrological and geomorphological processes. A review. Catena 128, 122-134. https://doi.org/10.1016/j.catena.2015.01.021.

Arnáez, J., Lana-Renault, N., Ruiz-Flaño, P., Pascual, N., Lasanta, T. 2017. Mass soil movement on terraced landscapes of the Mediterranean mountain areas: a case study in the Iberian Range, Spain. Cuadernos de Investigación Geográfica 43 (1), 83-100. https://doi.org/10.18172/cig.3211.

Bakker, M.M., Govers, G., Van Doorn, A., Quetier, F., Chouvardas, D., Rounsevell, M. 2008. The response of soil erosion and sediment export to land-use change in four areas of Europe: the importance of landscape pattern. Geomorphology 98, 213-226. https://doi.org/10.1016/j. geomorph.2006.12.027.

Beguería, S., López Moreno, J.I., Gómez Villar, A., Rubio, V., Lana-Renault, N., García-Ruiz, J.M. 2006. Fluvial adjustment to soil erosion and plant cover changes in the Central Spanish Pyrenees. Geografiska Annaler 88 (3), 177-186. https://doi.org/10.1111/j.14680459.2006.00293.x. 
Borselli, L., Cassi, P., Torri, D. 2008. Prolegomena to sediment and flow connectivity in the landscape: A GIS and field numerical assessment. Catena 75 (3), 268-277. https://doi. org/10.1016/j.catena.2008.07.006.

Buendia, C., Bussi, G., Tuset, J., Vericat, D., Sabater, S., Palau, A., Batalla, R.J. 2016. Effects of afforestation on runoff and sediment load in an upland Mediterranean catchment. Science of the Total Environment 540, 144-157. https://doi.org/10.1016/j.scitotenv.2015.07.005.

Burch, G.J., Bath, R.K., Moore, I.D., O’Loughlin, E.M. 1987. Comparative hydrological behaviour of forested and cleared catchments in southeastern Australia. Journal of Hydrology 90, 1942. https://doi.org/10.1016/0022-1694(87)90171-5.

Butzen, V., Seeger, M., Casper,M. 2011 . Spatial pattern and temporal variability of runoff processes in Mediterranean mountain environments - Acase study of the Central Spanish Pyrenees. Zeitschrift fur Geomorphologie 55, 25-48. https://doi.org/10.1127/0372-8854/2011/0055S3-0050.

Camera, C., Apuani, T., Masetti, M. 2014. Mechanisms of failure on terraced slopes: the Valtellina case (northern Italy). Landslides 11, 43-54. https://doi.org/10.1007/s10346-012-0371-3.

Calsamiglia, A., Fortesa, J., García-Comendador, J., Lucas-Borja, M.E., Calvo-Cases, A., Estrany. J. 2017. Spatial patterns of sediment connectivity in terraced lands: anthropogenic controls of catchment sensitivity. Land Degradation \& Development. https://doi.org/10.1002/ldr.2840.

Cavalli, M., Trevisani, S., Comiti, F., Marchi, L. 2013. Geomorphometric assessment of spatial sediment connectivity in small Alpine catchments. Geomorphology 188, 31-41. https://doi. org/10.1016/j.geomorph.2012.05.007.

Cavalli, M., Crema, S., Marchi, L. 2015. Guidelines on the Sediment Connectivity stand-alone application SedInConnect. Release: 2.0 and 2.1 [online] Available from: https://github.com/ HydrogeomorphologyTools.

Cavalli, M., Tarolli, P., Dalla Fontana, G., Marchi, L. 2016. Multi-temporal analysis of sediment source areas and sediment connectivity in the Rio Cordon catchment (Dolomites). Rendiconti Online Della Società Geologica Italiana 39, 27-30. https://doi.org/10.3301/ROL.2016.39.

Chartin, C., Evrard, O., Laceby, J.P., Onda, Y., Ottlé, C., Lefèvre, I., Cerdan, O. 2017. The impact of typhoons on sediment connectivity: lessons learnt from contaminated coastal catchments of the Fukushima Prefecture (Japan). Earth Surface Processes and Landforms 42 (2), 306317. https://doi.org/10.1002/esp.4056.

Chirino, E., Sánchez, J.R., Bonet, A., Bellot, J. 2001. Effect of afforestation and vegetation dynamics on soil erosion in a semi-arid environment (SE Spain). Transactions on Ecology and the Environment 46, 239-248.

Combes, F., Hurand, A., Meunier, M. 1994. La forêt de montagne: un remède aux crues. Actes des 23èmes Journées de l'Hydraulique. Crues et inondations. SHF, Nîmes, pp. 475-480.

Croke, J., Mockler, S., Fogarty, P., Takken, I. 2005. Sediment concentration changes in runoff pathways from a forest road network and the resultant spatial pattern of catchment connectivity. Geomorphology 68 (3-4), 257-268. https://doi.org/10.1016/j.geomorph.2004.11.020.

Cuadrat, J.M., Vicente-Serrano, S. 2008. Características espaciales del clima en La Rioja modelizadas a partir de Sistemas de Información Geográfica y técnicas de regresión espacial. Zubía monográfico 20, 119-142.

De Tar, W.R., Ross, J.J., Cunningham, R.L. 1980. Estimating the C factor in the Universal Soil Loss Equation for landscape slopes. Journal of Soil and Water Consservation 35 (1), 40-41.

D’Haen, K., Dusar, B., Verstraeten, G., Degryse, P., De Brue, H. 2013. A sediment fingerprinting approach to understand the geomorphic coupling in an eastern Mediterranean mountainous river catchment. Geomorphology 197, 64-75. https://doi.org/10.1016/j.geomorph.2013.04.038.

Dung, B.X., Hiraoka, M., Gomi, T., Onda, Y., Kato, H. 2015. Peak flow responses to strip thinning in a nested, forested headwater catchment. Hydrological Processes 29 (24), 5098-5108. https://doi.org/10.1002/hyp.10720. 
Gallart, F., Llorens, P., Latron, J. 1994. Studying the role of old agricultural terraces on runoff generation in a Mediterranean small mountainous basin. Journal of Hydrology 159, 291-303. https://doi.org/10.1016/0022-1694(94)90262-3.

García-Ruiz, J.M., Lana-Renault, N. 2011. Hydrological and erosive consequences of farmland abandonment in Europe, with special reference to the Mediterranean region - A review. Agriculture, Ecosystems and Environment 140, 317-338. https://doi.org/10.1016/j. agee.2011.01.003.

García-Ruiz, J.M., Martí-Bono, C., Arnáez, J., Beguería, S., Lorente, A., Seeger, M. 2000. Las cuencas experimentales de Arnás y San Salvador en el Pirineo Central: escorrentía y transporte de sedimento. Cuadernos de Investigación Geográfica 26, 23-40. https://doi. org/10.18172/cig.1061.

García-Ruiz, J.M., Arnáez, J., Beguería, S., Seeger, M., Martí-Bono, C., Regüés, D., LanaRenault, N., White, S. 2005. Flood generation in an intensively disturbed, abandoned farmland catchment, Central Spanish Pyrenees. Catena 59, 79-92. https://doi.org/10.1016/j. earscirev.2011.01.006.

García-Ruiz, J.M., Regüés, D., Alvera, B., Lana-Renault, N., Serrano-Muela, P., Nadal-Romero, E., Navas, A., Latron, J., Martí-Bono, C., Arnáez, J. 2008. Flood generation and sediment transport in experimental catchments affected by land use changes in the central Pyrenees. Journal of Hydrology 356, 245-260. https://doi.org/10.1016/j.jhydrol.2008.04.013.

García-Ruiz, J.M., López-Moreno, J.I., Vicente-Serrano, S.M., Lasanta, T., Beguería, S. 2011. Mediterranean water resources in a Global Change scenario. Earth-Science Reviews 105, 121-139. https://doi.org/10.1016/j.earscirev.2011.01.006.

Gay, A., Cerdan, O., Mardhel, V., Desmet, M. 2016. Application of an index of sediment connectivity in a lowland area. Journal of Soils and Sediments 16 (1), 280-293. https://doi. org/10.1007/s11368-015-1235-y.

González, C., García-Ruiz, J.M., Martí, C., White, S., Errea, M.P., Arnáez, J. 1997. Sediment sources in a small, abandoned farmland catchment, Central Spanish Pyrenees. Physics and Chemistry of the Earth 22 (3-4), 291-293. https://doi.org/10.1016/S0079-1946(97)00146-8.

Hewlett, J.D., Hibbert, A.R. 1967. Factors affecting the response of small watersheds to precipitation in humid areas. In: W.E. Sopper, H.W. Lull (Eds.), Forest Hydrology. Pergamon Press, UK, pp. 275-290.

Holko, L., Holzmann, H., de Lima, M.I.P., de Lima, J.L.M.P. 2015. Hydrological research in small catchments - an approach to improve knowledge on hydrological processes and global change impacts. Journal of Hydrology and Hydromechanics 63 (3), 181-182. https://doi. org/10.1515/johh-2015-0032.

Hümann, M., Schüler, G., Müller, C., Schneider, R., Johst, M., Caspari, T. 2011. Identification of runoff processes - The impact of different forest types and soil properties on runoff formation and floods. Journal of Hydrology 409, 637-649. https://doi.org/10.1016/j. jhydrol.2011.08.067

Keesstra, S.D. 2007. Impact of natural reforestation on floodplain sedimentation in the Dragonja basin, SW Slovenia. Earth Surface Processes and Landforms 32 (1), 49-65. https://doi. org/10.1002/esp.1360.

Lana-Renault, N., Regüés, D. 2007. Bedload transport under different flow conditions in a humandisturbed catchment in the Central Spanish Pyrenees. Catena 71, 155-163. https://doi. org/10.1016/j.catena.2006.04.029.

Lana-Renault, N., Regüés, D. 2009. Seasonal pattern of suspended sediment transport in an abandoned farmland catchment in the Central Pyrenees. Earth Surface Processes and Landforms 34 (9), 1291-1301. https://doi.org/10.1002/esp.1825. 
Lana-Renault, N., Latron, J., Regüés, D. 2007. Streamflow response and water-table dynamics in a sub-Mediterranean research catchment (Central Pyrenees). Journal of Hydrology 347, 497 507. https://doi.org/10.1016/j.jhydrol.2007.09.037.

Lana-Renault, N., Latron, J., Karssenberg, D., Serrano, P., Regüés, D., Bierkens, M.F.P. 2011. Differences in stream flow in relation to changes in land cover: a comparative study in two sub-Mediterranean mountain catchments. Journal of Hydrology 411, 366-378. https://doi. org/10.1016/j.jhydrol.2011.10.020.

Lana-Renault, N., Regüés, D., Serrano, P., Latron, J. 2014a. Spatial and temporal variability of groundwater dynamics in a sub-Mediterranean mountain catchment. Hydrological Processes 28, 3288-3299. https://doi.org/10.1002/hyp.9892.

Lana-Renault, N., Ruiz-Flaño, P., Llorente, J.A., Arnáez, J. 2014b. Respuesta hidrológica de una cuenca de bancales abandonados (Camero Viejo, La Rioja). In: J. Arnáez, P. GonzálezSampériz, T. Lasanta, B. Valero-Garcés (Eds.), Geoecología, cambio ambiental y paisaje. IPE-CSIC, Universidad de La Rioja, Logroño, pp. 311-320.

Lana-Renault, N., Nadal-Romero, E., Serrano-Muela, M.P., Alvera, B., Sánchez-Navarrete, P., Sanjuán, Y., García-Ruiz, J.M. 2014c. Comparative analysis of the response of various land covers to an exceptional rainfall event in the central Spanish Pyrenees, October 2012. Earth Surface Processes and Landforms 39, 581-592. https://doi.org/10.1002/esp.3465.

Lana-Renault, N., Karssenberg, D., Bierkens, M. in review. Changes in catchment hydrology during vegetation recovery: individual effects of vegetation and soils. Journal of Hydrology.

Lane, S.N., Reaney, S.M., Heathwaite, A.L. 2009. Representation of landscape hydrological connectivity using a topographically driven surface flow index. Water Resources Research 45 (8), W08423. https://doi.org/10.1029/2008WR007336.

Lasanta-Martínez, T., Vicente-Serrano, S.M., Cuadrat-Prats, J.M. 2005. Mountain Mediterranean landscape evolution caused by the abandonment of traditional primary activities: a study of the Spanish Central Pyrenees. Applied Geography 25 (1), 47-65. https://doi.org/10.1016/j. apgeog.2004.11.001.

Lasanta, T., Arnáez, J., Pascual, N., Ruiz-Flaño, P., Errea, P., Lana-Renault, N. 2017a. Spacetime process and drivers of land abandonment in Europe. Catena 149, 810-823. https://doi. org/10.1016/j.catena.2016.02.024.

Lasanta, T., Errea, M.P., Nadal-Romero, E. 2017b. Traditional agrarian landscape in the Mediterranean mountains. A regional and local factor analysis in the Central Spainsh Pyrenees. Land Degradation \& Development. https://doi.org/10.1002/ldr.2695.

Lasanta, T., Nadal-Romero, E., Errea, M.P. 2017c. The footprint of marginal agriculture in the Mediterranean mountain landscape: An analysis of the Central Spanish Pyrenees. Science of the Total Environment 599-600, 1823-2836. https://doi.org/10.1016/j.scitotenv.2017.05.092.

Latron, J., Gallart, F. 2007. Seasonal dynamics of runoff-contributing areas in a small mediterranean research catchment (Vallcebre, Eastern Pyrenees). Journal of Hydrology 335, 194-206. https://doi.org/10.1016/j.jhydrol.2006.11.012.

Latron, J., Gallart, F. 2008. Runoff generation processes in a small Mediterranean research catchment (Vallcebre, Eastern Pyrenees). Journal of Hydrology 358, 206-220. https://doi. org/10.1016/j.jhydrol.2008.06.014.

Latron, J., Soler, M., Llorens, P., Gallart, F. 2008. Spatial and temporal variability of the hydrological response in a small Mediterranean research catchment (Vallcebre, Eastern Pyrenees). Hydrological Processes 22 (6), 775-787. https://doi.org/10.1002/hyp.6648.

Lesschen, J.P., Cammeraat, L.H., Nieman, P. 2008. Erosion and terrace failure due to agricultural land abandonment in a semi-aridenvironment. Earth Surface Processes and Landforms 33, 1574-1584. https://doi.org/10.1002/esp.1676. 
Lizaga, I., Quijano, L., Palazón, L., Gaspar, L., Navas, A. 2016. Enhancing Connectivity index to assess the effects of land use changes in a Mediterranean catchment. Land Degradation \& Development. https://doi.org/10.1002/ldr.2676.

Llorente-Adán, J.A., Lana-Renault, N., Galilea, I., Ruiz-Flaño, P. 2015. The hydrological response of a small catchment after the abandonment of terrace cultivation. A study case in northwestern Spain. Geophysical Research Abstracts 17, EGU2015-173-1.

López-Moreno, J.I., Beniston, M., García-Ruiz, J.M. 2008. Environmental change and water management in the Pyrenees: Facts and future perspectives for Mediterranean mountains. Global and Planetary Change 66 (3-4), 300-312. https://doi.org/10.1016/j. gloplacha.2007.10.004.

López-Moreno, J.I., Vicente-Serrano, S.M., Morán-Tejeda, E., Zabalza, J., Lorenzo-Lacruz, J., García-Ruiz, J.M. 2011. Impact of climate evolution and land use changes on water yield in the Ebro basin. Hydrology and Earth System Sciences 15, 311-322. https://doi.org/10.5194/ hess-15-311-2011.

López-Vicente, M., Lana-Renault, N., García-Ruiz, J.M., Navas, A. 2011. Assessing the potential effect of different land cover management practices on sediment yield from an abandoned farmland catchment in the Spanish Pyrenees. Journal of Soils and Sediments 11 (8), 14401455. https://doi.org/10.1007/s11368-011-0428-2.

López-Vicente, M., Poesen, J., Navas, A., Gaspar, L. 2013a. Predicting runoff and sediment connectivity and soil erosion by water for different land use scenarios in the Spanish PrePyrenees. Catena 102, 62-73. https://doi.org/10.1016/j.catena.2011.01.001.

López-Vicente, M., Navas, A., Gaspar, L., Machín, J. 2013b. Advanced modelling of runoff and soil redistribution for agricultural systems: the SERT model. Agricultural Water Management 125, 1-12. https://doi.org/10.1016/j.agwat.2013.04.002.

López-Vicente, M., Pérez-Bielsa, C., López-Montero, T., Lambán, L.J., Navas, A. 2014. Runoff simulation with eight different flow accumulation algorithms: Recommendations using a spatially distributed and open-source model. Environmental Modelling \& Software 62, 1121. https://doi.org/10.1016/j.envsoft.2014.08.025.

López-Vicente, M., Nadal-Romero, E., Cammeraat, E.L.H. 2017a. Hydrological connectivity does change over 70 years of abandonment and afforestation in the Spanish Pyrenees. Land Degradation \& Development 28 (4), 1298-1310. https://doi.org/10.1002/ldr.2531.

López-Vicente, M., Sun, X., Onda, Y., Kato, H., Gomi, T., Hiraoka, M. 2017b. Effect of tree thinning and skidding trails on hydrological connectivity in two Japanese forest catchments. Geomorphology 292, 104-114. https://doi.org/10.1016/j.geomorph.2017.05.006.

Lorente, A., Martí, C., Beguería, S., Arnáez, J., García-Ruiz, J.M. 2000. La exportación de sedimento en suspensión en una cuenca de campos abandonados, Pirineo Central. Cuaternario y Geomorfología 14 (1-2), 21-34.

MacDonald, D., Crabtree, J.R., Wiesinger, G., Dax, T., Stamou, N. Fleury, P., Gutérrez Lazpita, J., Gibon, A. 2000. Agricultural abandonment in mountain areas of Europe: environmental consequences and policy response. Journal of Environmental Management 59, 47-69. https:// doi.org/10.1006/jema.1999.0335.

Marchamalo, M., Hooke, J.M., Sandercock, P.J. 2016. Flow and sediment connectivity in semi-arid landscapes in SE Spain: patterns and controls. Land Degradation \& Development 27 (4), 1032-1044. https://doi.org/10.1002/ldr.2352.

Martínez-Mena, M., Albaladejo, J., Castillo, V.M. 1998. Factors influencing surface runoff generation in a Mediterranean semi-arid environment: Chimaco watershed, SE Spain. Hydrological Processes 12 (5), 741-754. https://doi.org/10.1002/(SICI)10991085(19980430)12:5<741::AID-HYP622>3.0.CO;2-F. 
Martínez-Murillo, J.F., López-Vicente, M. 2017. Effect of salvage logging and check-dams on simulated hydrological connectivity in a burned area. Land Degradation \& Development. https://doi.org/10.1002/ldr.2735.

Meerkerk, A.L., van Wesemael, B., Bellin, N. 2009. Application of connectivity theory to model the impact of terrace failure on runoff in semi-arid catchments. Hydrological Processes 23 (19), 2792-2803. https://doi.org/10.1002/hyp.7376.

Miller, J.D., Nyhan, J.W., Yool, S.R. 2003. Modeling potential erosion due to the Cerro Grande Fire with a GIS-based implementation of the Revised Universal Soil Loss Equation. International Journal of Wildland Fire 12, 85-100. https://doi.org/10.1071/WF02017.

Molinillo, M., Lasanta, T., García-Ruiz, J.M. 1997. Managing mountainous degraded landscape after farmland abandonment in the Central Spanish Pyrenees. Environmental Management 21(4), 587-598. https://doi.org/10.1007/s002679900051.

Nadal-Romero, E., Lana-Renault, N., Serrano-Muela, P., Regüés, D., Alvera, B., García-Ruiz, J.M. 2012. Sediment balance in four catchments with different land cover in the Central Spanish Pyrenees. Zeitschrift für Geomorphologie 56 (3), 147-168. https://doi.org/10.1127/03728854/2012/S-00109.

Nadal-Romero, E., Cammeraat, E., Serrano-Muela, M.P., Lana-Renault, N., Regüés, D. 2016. Hydrological response of an afforested catchment in a Mediterranean humid mountain area: a comparative study with a natural forest. Hydrological Processes 30, 2717-2733. https://doi. org/10.1002/hyp.10820.

Navas, A., Machín, J., Soto, J. 2005. Assessing soil erosion in a Pyrenean mountain catchment using GIS and fallout 137Cs. Agriculture, Ecosystems \& Environment 105 (3), 493-506. https://doi.org/10.1016/j.agee.2004.07.005.

Navas, A., Machín, J., Beguería, S., López-Vicente, M., Gaspar, L. 2008. Soil properties and physiographic factors controlling the natural vegetation re-growth in a disturbed catchment of the Central Spanish Pyrenees. Agroforestry Systems 72, 173-185. https://doi.org/10.1007/ s10457-007-9085-2.

Nunes, J.P., Bernard-Jannin, L., Rodríguez Blanco, M.L., Santos, J.M., de Oliveira Alves Coelho, C., Keizer, J.J. 2016. Hydrological and erosion processes in terraced fields: observations from a humid mediterranean region in northern Portugal. Land Degradation \& Development. https://doi.org/10.1002/ldr.2550.

Ore, G., Bruins, H.J. 2012. Design features of ancient agriculture terrace walls in the Negev Desert: human-made geodiversity. Land Degradation \& Development 23, 409-418. https:// doi.org/10.1002/ldr.2152.

Ortigosa, L., García-Ruiz, J.M., Gil, E. 1990. Land reclamation by reforestation in the Central Pyrenees. Mountain Research and Development 10 (3), 281-288. https://doi. org/10.2307/3673607.

Ortíz-Rodríguez, A.J., Borselli, L., Sarocchi, D. 2017. Flow connectivity in active volcanic areas: Use of index of connectivity in the assessment of lateral flow contribution to main streams. Catena 157, 90-111. https://doi.org/10.1016/j.catena.2017.05.009.

Oserín, M. 2006. Cambios en la gestión del territorio de una montaña media mediterránea y sus impactos medioambientales. Unpublished $\mathrm{PhD}$, University of La Rioja, Logroño, $368 \mathrm{pp}$.

Palleiro, L., Rodríguez-Blanco, M.L., Taboada-Castro, M.M., Taboada-Castro, M.T. 2014. Hydrological response of a humid agroforestry catchment at different time scales. Hydrological Processes 28 (4), 1677-1688. https://doi.org/10.1002/hyp.9714.

Panagos, P., Borrelli, P., Meusburger, K., Alewell, C., Lugato, E., Montanarella, L. 2015. Estimating the soil erosion cover-management factor at the European scale. Land Use Policy 48, 38-50. https://doi.org/10.1016/j.landusepol.2015.05.021. 
Piégay, H., Walling, D., Landon, N., He, Q., Liébault, F., Petiot, R. 2004. Contemporary changes in sediment yield in an alpine mountain basin due to afforestation (the upper Drôme in France). Catena 55 (2), 183-212. https://doi.org/10.1016/S0341-8162(03)00118-8.

Planchon, O., Darboux, F. 2001. A fast, simple and versatile algorithm to fill the depressions of digital elevation models. Catena 46 (2-3), 159-176. https://doi.org/10.1016/S03418162(01)00164-3.

Poyatos, R., Latron, J., Llorens, P. 2003. Land use and land cover change after agricultural abandonment: the case of a Mediterranean Mountain area (Catalan Pre-Pyrenees). Mountain Research and Development 23 (4), 362-368.

Preti, F., Guastini, E., Penna, D., Dani, A., Cassiani, G., Boaga, J., Deiana, R., Romano, N., Nasta, P., Palladino, M., Errico, A., Giambastiani, Y., Trucchi, P., Tarolli, P. 2017. Conceptualization of water flow pathways in agricultural terraced landscapes. Land Degradation \& Development. https://doi.org/10.1002/ldr.2764.

Prosdocimi, M., Burguet, M., Di Prima, S., Sofia, G., Terol, E., Rodrigo-Comino, J., Cerdà, A., Tarolli, P. 2017. Rainfall simulation and Structure-from-Motion photogrammetry for the analysis of soil water erosion in Mediterranean vineyards. Science of the Total Environment 574, 204-215. https://doi.org/10.1016/j.scitotenv.2016.09.036.

Puigdefábregas, J. 2005. The role of vegetation patterns in structuring runoff and sediment fluxes in drylands. Earth Surface Processes and Landforms 30, 133-147. https://doi.org/10.1002/ esp. 1181 .

Quiñonero-Rubio, J.M.,Boix-Fayos, C., De Vente, J. 2013. Development and application of a multifactorial sediment connectivity index at the catchment scale. Cuadernos de Investigación Geográfica 39, 203-223. https://doi.org/10.18172/cig.1988.

Quiñonero-Rubio, J.M., Nadeu, E., Boix-Fayos, C., De Vente, J. 2016. Evaluation of the effectiveness of forest restoration and check-dams to reduce catchment sediment yield. Land Degradation \& Development 27, 1018-1031. https://doi.org/ 10.1002/ldr.2331.

Reaney, S.M., Bracken, L.J., Kirkby, M.J. 2014. The importance of surface controls on overland flow connectivity in semi-arid environments: Results from a numerical experimental approach. Hydrological Processes 28 (4), 2116-2128. https://doi.org/10.1002/hyp.9769.

Regüés, D., Serrano-Muela, P., Nadal-Romero, E., Lana-Renault, N. 2012. Análisis de la variabilidad de la infiltración en un gradiente de degradación de usos del suelo en el Pirineo Central. Cuaternario y Geomorfología 26 (1-2), 9-28.

Regüés, D., Badía, D., Echeverría, M.T., Gispert, M., Lana-Renault, N., León, J., Nadal-Romero, E., Pardini, G., Serrano-Muela, P. 2017. Analysing the effect of land uses and vegetation cover on soil infiltration in three contrasting environments in north east Spain. Cuadernos de Investigación Geográfica - Geographical Research Letters 43 (1), 141-169. https://doi. org/10.18172/cig.3164.

Richard, D., Mathys, N. 1999. Historique, contexte technique et scientifique des BVRE de Draix. In: N. Mathys (Ed.), Caractéristiques, données disponibles et principaux résultats acquis au cours des dix ans de suivi. Actes du séminaire Les bassins versants expérimentaux de Draix. Cemagref-Editions, Coll. Actes de colloques, Grenoble, pp. 11-28.

Romero-Díaz, A., Ruiz-Sinoga, J.D., Robledano-Aymerich, F., Brevik, E.C., Cerdà, A. 2017. Ecosystem responses to land abandonment in Western Mediterranean Mountains. Catena 149, 824-835. http://doi.org/10.1016/j.catena.2016.08.013.

Sandercock, P.J., Hooke, J.M. 2011. Vegetation effects on sediment connectivity and processes in an ephemeral channel in SE Spain. Journal of Arid Environments 75 (3), 239-254. https://doi. org/10.1016/j. jaridenv.2010.10.005.

Sanjuán, Y., Gómez-Villar, A., Nadal-Romero, E., Álvarez-Martínez, J., Arnáez, J., SerranoMuela, M.P., Rubiales, J.M., González-Sampériz, P., García-Ruiz, J.M. 2016. Linking land 
cover changes in the sub-alpine and montane belts to changes in a torrential river. Land Degradation \& Development 27, 179-189. https://doi.org/10.1002/ldr.2294.

Schwab, G.O., Fangmeier, D.D., Elliot, W.J. 1996. Soil and water management systems. John Wiley and Sons, New York, $371 \mathrm{pp}$.

Seeger, M., Ries, J.B. 2008. Soil degradation and soil surface process intensities on abandoned fields in Mediterranean mountain environments. Land Degradation \& Development 19, 488501. https://doi.org/10.1002/ldr.854.

Seeger, M., Errea, M.P., Beguería, S., Arnáez, J., Martí-Bono, C., García-Ruiz, J.M. 2004. Catchment soil moisture and rainfall characteristics as determinant factors for discharge/ suspended sediment hysteretic loops in a small headwater catchment in the Spanish Pyrenees. Journal of Hydrology 288, 299-311. https://doi.org/ 10.1016/j.jhydrol.2003.10.012.

Serrano-Muela, M.P., Lana-Renault, N., Nadal-Romero, E., Regüés, D., Latron, J., MartínBono, C., García-Ruiz, J.M. 2008. Forests and their hydrological effects in Mediterranean Mountains. The case of the Central Spanish Pyrenees. Mountain Research and Development 28 (3-4) 279-285. https://doi.org/10.1659/mrd.0876.

Serrano-Muela, M.P., Regüés, D., Nadal-Romero, E. 2012. Trascolación y escorrentía cortical en la cuenca experimental de San Salvador, Pirineo Central español. Cuaternario y Geomorfología $26(1-2), 49-72$.

Serrano-Muela, P., Nadal-Romero, E., Lana-Renault, N. 2014. La relación suelo-vegetación y su influencia en el comportamiento hidrológico de distintos ambientes vegetales. In: J. Arnáez, P. González-Sampériz, T. Lasanta, B. Valero-Garcés (Eds), Geoecología, cambio ambiental y paisaje. IPE-CSIC, Universidad de La Rioja, pp. 217-228.

Solé-Benet,A., Lázaro, R., Domingo,F., Cantón, Y.,Puigdefábregas, J. 2010. Why most agricultural terraces in steep slopes in semiarid SE Spain remain well preserved since their abandonment 50 years ago? Pirineos 165, 215-235. https://doi.org/10.3989/Pirineos.2010.165011.

Tarboton, D.G. 1997. A new method for the determination of flow directions and upslope areas in grid digital elevation models. Water Resources Research 33, 309-319. https://doi. org/10.1029/96WR03137.

Tarboton, D.G. 2013. TauDEM 5.1, Terrain Analysis Using Digital Elevation Models [online] Available from: https://hydrology.usu.edu/taudem/taudem5/.

Tzanopoulos, J., Mitchley, J., Pantis, J.D. 2007. Vegetation dynamics in abandoned crop fields on a Mediterranean island: development of succession model and estimation of disturbance thresholds. Agriculture, Ecosystems \& Environment 120, 370-376. https://doi.org/10.1016/j. agee.2006.10.011.

Vallauri, D.R., Aroson, J., Barbero, M. 2002. An analysis of forest restoration 120 years after reforestation on badlands in the Southwestern Alps. Restoration Ecology 10 (1), 16-26. https://doi.org/10.1046/j.1526-100X.2002.10102.x.

Verburg, P.H., Overmars, K.P. 2009. Combining top-down and bottom-up dynamics in land use modeling: exploring the future of abandoned farmlands in Europe with Dyna-CLUE model. Landscape Ecology 24 (9), 1167-81. https://doi.org/10.1007/s10980-009-9355-7.

Vigiak, O., Borselli, L., Newham, L.T.H., McInnes, J., Roberts, A.M. 2012. Comparison of conceptual landscape metrics to define hillslope-scale sediment delivery ratio. Geomorphology 138, 74-88. https://doi.org/10.1016/j.geomorph.2011.08.026.

Whipkey, R.Z. 1965. Subsurface storm-flow from forested slopes. Bulletin of the International Association of Hydrological Sciences 10,74-85.https://doi.org/10.1080/02626666509493392. 